\title{
Impact of Income Inequality on Health and Education in Africa: The Long run Role of Public Spending with Short Run Dynamics
}

Tonmoy Chatterjee ( $\nabla$ tonmoychatterjee.economics@gmail.com ) Ananda Chandra College https://orcid.org/0000-0001-9666-479X

Ghirmai Tesfamariam Teame

College of Business and Social Sciences, Adi-Keih

\section{Research}

Keywords: Health, Education, Income Inequality, Public Investment, short-run Causality, Long-run Causality, Panel cointegration

Posted Date: February 15th, 2022

DOl: https://doi.org/10.21203/rs.3.rs-1265490/v1

License: (c) (i) This work is licensed under a Creative Commons Attribution 4.0 International License. Read Full License 


\title{
Impact of Income Inequality on Health and Education in Africa: The Long run Role of Public Spending with Short Run Dynamics
}

\author{
Tonmoy Chatterjee \\ Department of Economics, Ananda Chandra College, Jalpaiguri, India \\ and \\ Ghirmai Tesfamariam Teame \\ Department of Economics, College of Business and Social Sciences, Adi-Keih, Eritrea.
}

Address for Correspondence-

Tonmoy Chatterjee

Department of Economics,

Ananda Chandra College, Jalpaiguri,

India, PIN-735101

Email- tonmoychatterjee.economics@gmail.com 


\title{
Impact of Income Inequality on Health and Education in Africa: The Long run Role of Public Spending with Short Run Dynamics
}

\begin{abstract}
In this paper we empirically investigated the long-run behavior of income inequality on the pattern of major social sector elements like health and education in African continent. In this context we have used a data set for 31 African countries for the period of 1980-2017. Our empirical model amalgamated with the rationality of theoretical underpinning claims that income inequality adversely affects health and education both in Short-run and long-run. However, it also claims that in the presence of efficient state intervention in the form of investment in both health and education unambiguously can better-off health and education scenarios in long-run, although the curse of income disparity remains with uphold in short-run. Apart from this, the present study also finds the threshold levels of government investments are required to make the process of better-off more sustainable for both health and education in the presence of income inequality in Africa. These results could be important for policymaking to boost health, education in Africa under the cloud of income disparity.
\end{abstract}

Keywords: Health, Education, Income Inequality, Public Investment, short-run Causality, Long-run Causality, Panel cointegration

JEL Classification: I14, I25, H51, H52, C23 


\section{Introduction}

Developed and developing countries have witnessed some widened disparities in education, income and health during their quest for economic development. These inequalities are described by most, as one of the most important problems of our time and several have emphasized its social costs (Pickett and Wilkinson, 2015). Others have called for redistributive policy interventions, not only for reasons of fairness but also to avoid economic and social costs of wide income gaps. Thus, investing in health and education has recently constituted important social objectives because a reasonably good level of human capital increases a laborer's skills, productivity, income and quality of life.

The quest for economic development walks with several socio-economic opportunities or challenges like health and education. Education is considered as the backbone towards smoothest potential path of development, while health can be referred as the long-run counterpart of education to development. For instance, the production world treats education as a component by which an unskilled human can be converted to a skilled one and thereby creating the prospect of human capital formation. Consequently, human capital formation endogenously determines the path of economic growth and obviously economic development (Romer, 1990). Similarly, better health increases nutritional efficiency and ability to attend more working days and hence, creates a positive effect on individual productivity and returns to human capital.

According to Eggoh, Houeninvo \& Sossou (2015), association between health, education with economic growth is likely to be moved in a positive manner; despite the fact that several nations with high economic growth have been suffering from lack of advance or poor education and health scenario, for instance, the example of South Africa and Nigeria can be considered. In this context, issues like income distribution are considered to play a pivotal role in explaining and examining the direction of improvement of education and health in developing countries. Wilkinson and Pickett (2006) conclude 
from their comprehensive review of the literature that the large majority of more than 150 empirical studies suggest that "health is less good in societies where income differences are bigger". Developing countries like South Africa and Nigeria are experiencing economic growth rate of 2.71(2017-18), 3.1(2017-18), respectively, while the same nations also ascribing gini coefficient of 0.63 and 0.46 correspondingly. Therefore, income inequality can be conjectured as one of the benevolent element behind the prevailing crisis related to health and education in developing economies. Income disparities have widened in various developing countries during the process of economic globalization associated with high economic growth. Thus, critics have called for redistributive policy interventions, not only for reasons of fairness but also to avoid economic and social costs of wide income gaps. Impaired health and education could add considerably to such costs and hence, government investment in such social sectors become quite essential (Deaton, 2003; Herzer \& Nunnenkamp, 2015).

Under this backdrop, the present paper tries to explore the theoretical basis and empirical evidence for long-run association between income inequality and health, and income inequality and education among the labor rich or developing countries in Africa. Here we want to check how and in which way income inequality affects the growing trajectory of inequality in health and education? More specifically, we want to illustrate that whether income inequality affects health and education directly or indirectly through corresponding public investment channels.

We believe that our paper will contribute to the existing literature in the following ways. First, we have used a holistic way by introducing a theoretical background and precise empirical method to trace the impact of income inequality on health and education in African countries. Second, unlike other empirical studies on African continent, this paper examines the long-run impact of public spending in social sectors to curb adversity of income inequality. Third, this paper uses a hitherto commonly untested interaction between public health and public education investments with 
income inequality, which is expected to give us the threshold levels of public health and public education investments required for the African countries to optimize health and education status. Thus, to the best of our knowledge, this paper is the first of its kind in examining the long run effects of income inequality on health and education status in African countries.

The rest of the paper is organized as follows: Section 3 presents the relations between health, education and income inequality followed by a brief review of the literature, presented in Section 2. Section 4 deals with variables, data and methodology. Section 5 presents econometric results and discussion; and the paper ends with Section 6 which presents conclusion and policy implications.

\section{Brief Review of Literature}

Income is associated with mortality, as well as with other health outcomes, probably because it is needed to buy healthy food, good housing in a safe environment, quality health care, etc. Moreover, health is considered among the basic sources of productivity and can be an agent to quality of labor. Improvement in health may ensure higher life expectancy that may lead to longer working life, higher rewards and achievements to the skilled and educated class. There are evidences that show a strong positive relationship between income and health. Thus, a higher income may potentially determine a better health status via access to improved health services, clean drinking water, nutritious diet and better hygiene. Health and education determine higher efficiency and consistency at work that may ensure higher monetary rewards for working people which may reduce the economic inequalities in general and particularly among the working class. In this section, we review the literature on the relationship between income inequality and health status as well as income inequality and education. First, we discuss the literature which cultured the issue of health and inequality. Second, we consider the studies which analyzed the aspect of education and inequality. 
In the literature there are widely discussed mechanisms to connect income inequality and health. The first one is the absolute income hypothesis that postulates a non-linear relationship between income and health status, and individual's health status increases with individual income but at a decreasing rate. The second mechanism proposed in the literature is the relative income hypothesis which postulates that an individual's relative income position within a country affects the individual's health status. For example, lower relative income increases chronic stress of individuals, due to an increased feeling of deprivation, which is translated into an unhealthier life. The last mechanism is the idea of societal effects and, in particular, the effect of increased violence due to higher income inequality, which might lead to higher death rates but also to increased levels of stress, which then translate into worse health outcomes (Alesina et al., 1999; Leigh et al., 2009; Deaton, 2003 and Gravelle, 1998).

There is an extensive literature examining income inequality in relation to health. Early reviews came to different interpretations of the evidence, though a majority of the studies reported that health status tends to be worse in more unequal societies. It is Preston (1975) who first critically evaluated the linear along with non-linear association between health status and average per capita incomes across nations. The result of the study shows that among poor nations, increase in per capita income and income equality are strongly associated with increases in life expectancy; however, the relationship flattens out and is weaker or even missing among the wealthiest nations. It reveals that the diminishing returns to personal income shows an adverse impact of income inequality on health status (Gravelle, 1998). Moreover, using data of 50 countries, Rodgers (1979 reports a negative association between income inequality and life expectancy among the countries. Wilkinson (1992 and 1997) concludes in favor of a negative impact of income inequality on health for OECD countries after controlling for cross country differences in income levels. Similarly, Deaton (2003) reports that income inequality is significantly attached with poverty and deprivation, and such things may 
not cooperate to boost up population health conditions for a representative nation. Lynch et al. (2004) also report that there seems to be consistent evidence for a negative impact of income inequality on health outcomes for the US; on the contrary income inequality does not have a negative effect on health status, at least among the wealthier nations in Europe. Studies by Hoffmann, 1986; Cavelaars et al.1998; Dahl et al., 2006; Eikemo et al., 2008; Mackenbach et al., 1997; Mackenbach et al, 2008; which compares the degree of health inequality between countries that have different degrees of income inequality reveals that countries with smaller income inequalities, such as the Scandinavian countries, often have larger mortality inequalities than countries with larger income inequalities, such as the USA or Mediterranean countries (Hoffmann, 2011)..Again, rank in income or social distribution matters and relative analysis of one's own well-being with higher ranked individuals in relevant reference clusters can also be stressful (Leigh \& Jencks, 2007). Unequal societies create additional nerve-racking strategies of dominance, conflict and submission (Wilkinson, 2000). Consequently, chronic stress damages health conditions by permanently distressing the physiologic balance (Sapolsky, 2004).

Apart from the adverse impact of income disparity on health, a slight improvement of life expectancy has also been traced due to income inequality in developed countries (Herzer \& Nunnenkemp, 2015). Moreover, Herzer and Nunnenkemp (2015) also use panel cointegration for developing countries and claim similar relationship between health and inequality. Similarly, Van Doorslaer and Koolman (2004) claim that countries with larger income inequalities usually have larger inequalities in selfassessed health between income group. In addition to this, Ross et al. (2000) observe a positive relationship between mortality and income inequality for urban Canada and United States, confirming the above findings. By disaggregating the matter among infant mortality rate, inequality and growth, Ray and Linden (2018) report positive impact of income dispersion on health even in poor countries. To give reasons behind such improvement the literature endorses the potentiality of expenditure on health. The 
long-term demographic and economic data for developed OECD nations suggest that rise in human capital formation during transition periods enhancing the tempo of economic growth permanently and in turn the longevity of population can also increase. Rise in longevity can also be met up by both higher rates of private and public investments for health (Casasnovas et al. 2005; Cervellati \& Sunde 2005; Aisa \& Pueyo, 2006). Similarly, detailed studies by Claus et al. (2012) and Anderson et al. (2017) show that government spending on education and health significantly decreases income inequality.

The predominant theoretical framework for studying education and income inequality focuses on how education increases skills, improves problem-solving, enhances employment prospects, and thus opens access to other resources. In real life, however, education is viewed not only as increasing human capital but as a colander more than a ladder (Stevens, Armstrong \& Arum, 2008) and owing this an institution generates disparity across generations (Grodsky \& Jackson, 2009; Hout, 2012; Nash, 1990; Saha, 2008). The mechanisms of their production of inequality are diverse, encompassing systematic differences in school resources, quality of instruction, academic opportunities, peer influences, or teacher expectations (Grodsky \& Jackson, 2009; Saha, 2008; Walsemann, Gee \& Ro, 2013). The dual role of education, both engendering and constraining social opportunities, has been recognized from the discipline's inception (Gerth \& Mills, 1946) and has remained the dominant perspective in the sociology of education (Bourdieu \& Passeron, 1990; Stevens, Armstrong \& Arum, 2008).

There is also a strong association between education and income, partly because higher education provides better opportunities on the labour market. For example, Schultz (1963) and Becker (1964), in the theory of human capital, show that education (human capital development) increases the skills and competencies of individuals and their productivity which leads to higher wages and greater welfare and diminishes economic inequality. On the one hand, rising wage inequality should encourage investments in 
education mainly because it raises the return to education. Topel (1997) observes a faster skill accumulation as a result of rising returns. This increase in the supply of skills should eventually mitigate the increase in inequality.

Some of the available literature that examines the relationship between education and income inequality are summarized below. For example, by developing an overlapping generation model with intergenerational transmissions, Galor and Zeira (1993) suggest that the initial distribution of wealth is crucial to determine individuals' educational choices and the aggregate output both in the short and in the long run. Along the same line of reasoning, Banerjee and Newman (1993) suggest that the pattern of occupational (educational) choice is shaped by the initial distribution of wealth. Similarly, Perotti (1996) concludes that more equal societies have higher rates of investment in education. Using household surveys for 35 countries, Filmer and Pritchett (1999) demonstrate that economic status of households is correlated with reduced school attainment in the poorest 40 percent of the population. Similarly, Flug et al. (1998), based on macro panel data, suggest that credit market imperfections as well as more unequal income distribution negatively affect secondary school enrollments, confirming the above finding. On the other hand, using an unbalanced panel of 108 countries for the period 1960-95, Checchi (2003) reports a robust negative correlation between income inequality and secondary education enrolments, supporting the view that poor families are prevented from accessing school by their low incomes. Thus, greater income inequality reduces access to school (EU, 2012).

\section{Nexus between Health (or Education) and Income Inequality: Theoretical underpinning}

Following Chatterjee and Dinda (2015) and considering the assumption of open economy, the health output is produced using health capital, $H_{K}$, for given technology. Therefore, intensive form production function corresponding to health of any economy is

$H=f\left(H_{K}\right) ; f^{\prime}>0, f^{\prime \prime}<0$

Similarly, for education we assume that the intensive form production function corresponding to education of any economy is

$E=g\left(E_{K}\right) ; g^{\prime}>0, g^{\prime \prime}<0$ 
where, $E_{K}$ is the capital specific to education. The health and education of the economy, $H$ and $E$, depend only on the volume of health and education capital respectively. Effectiveness of capital investment in health and education are subject to the availability of proper social infrastructure. Social infrastructure of developing economies is adversely affected owing to the existence of income inequality (INQ). INQ is unavoidable and it has an inherent relation with the social process augmenting with health and education. Only ample amount of investment in health and education can eliminate the adverseness of income disparity. Health (or Education) per unit specificcapital investment $A_{H}$ (or $A_{E}$ ) may be a decreasing (increasing) function of technological improvement. For simplicity, this paper assumes a constant $A_{H}$ (or $A_{E}$ ). Health (or Education) is generated directly with health investment (or education investment) but inversely with income inequality, i.e.,

$$
\begin{gathered}
H=A_{H} H_{K} / I N Q \\
E=A_{E} E_{K} / I N Q
\end{gathered}
$$

A higher value of $H_{K}$ (or $E_{K}$ ) suggests more availability of better health (or education) in the economy (Eggoh, Houeninvo \& Sossou, 2015). The choice of health and education level depends on their availability and accessibility for all. It suggests that health and education status decreases owing to higher income disparity for given other inputs. Thus, stock of specific-capital (health or education) and persistence of inequality jointly determine health (or education) in long run. Therefore, taking log of equations (3) and (4) we get the following long-run relations,

$\ln H=\ln A+\ln H_{K}-\ln I N Q$

$\ln E=\ln A+\ln E_{K}-\ln I N Q$

Differentiation of equations (5) and (6) give us the following specifications

$$
\begin{gathered}
\hat{H}=\hat{H}_{K}-I N \hat{Q} \\
\hat{E}=\hat{E}_{K}-I N \hat{Q}
\end{gathered}
$$

where, ' $\wedge$ ' stands to illustrate the proportionate change of the respective variable. Equations (7) and (8) represent the theoretical priors regarding the association among health, health expenditure and income inequality, as well as education, education capital and income inequality, respectively. We can also depict the same in terms of 
Figure 1, where the right panel shows that $\mathrm{INQ}_{2}$ is the threshold level of inequality above which only the economy can enjoy the benefit of investment in health and education. Similarly, the left panel illustrates $\mathrm{H}_{\mathrm{K} 2}$ and $\mathrm{E}_{\mathrm{K} 2}$ as the threshold level of investment in health and education respectively to achieve the upward trajectory of $\mathrm{H}$ INQ (or E-INQ) schedule.

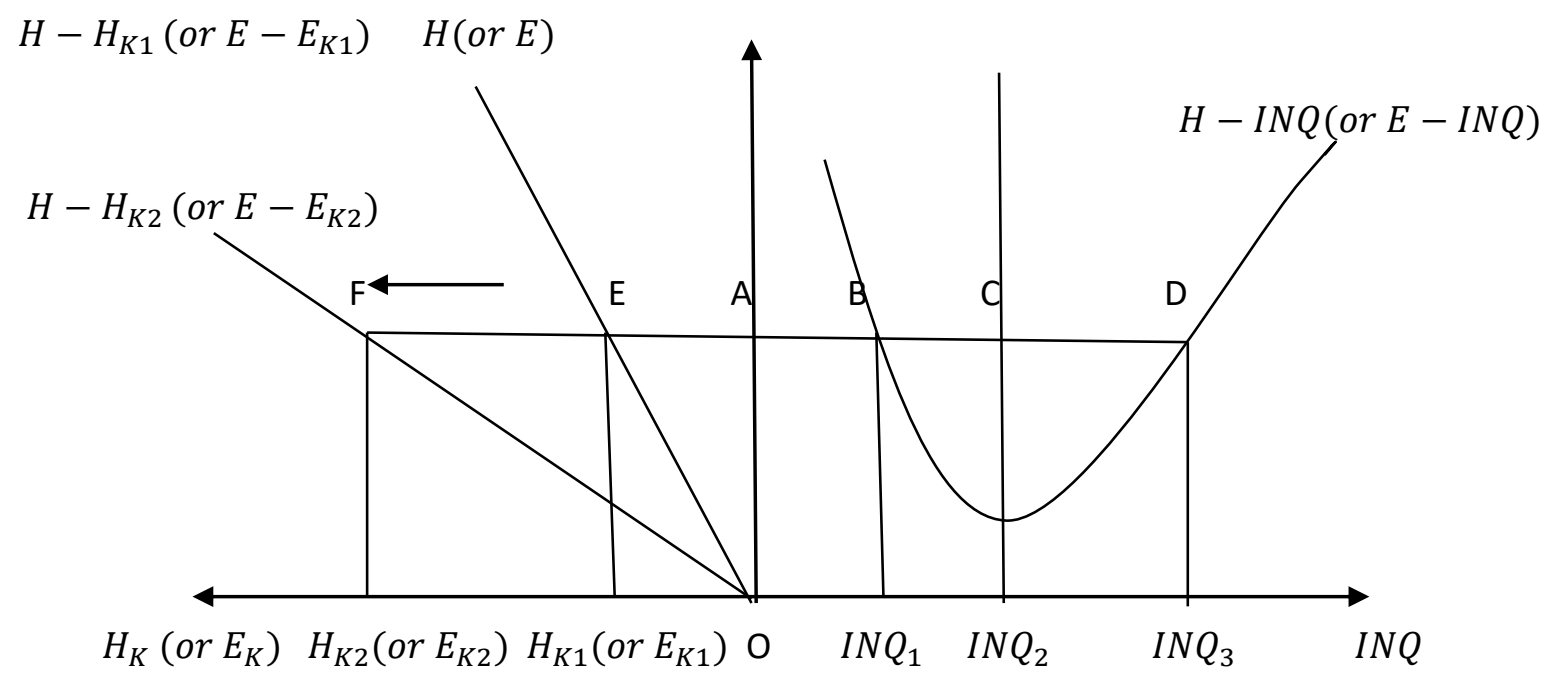

Figure-1: Determination of threshold health and education expenditures

This theory gives us couple of empirically examinable hypothesis. First, whether the nexus between health (or education) and income inequality is valid only in short-run or it's a long-run journey? Second, does investment in health (or education) can improve health (or education) scenario even in the presence of acute income inequality? Third, following the second point the theory is also asking us to derive the threshold level of investment are needed to better off both health and education by offsetting the adverse effect of income inequality.

\section{Variables, Data and Methodology}

Our objective is to examine the effect of income inequality on health and education in African countries using plausible panel data techniques. Further, we also look into the effectiveness of such inequality on the said objectives in the wake of public domain or in simple word under the nurturing of government in the form of government expenditure. In this section, we present the details of variables of our interest, data description and its descriptive statistics, and empirical models and also discuss some econometric issues. 


\subsection{Variables and Data}

Contemporary socio-economic conditions of most of the countries in Africa reveal a social draught prone illustration owing to human development criterion. Prevalence of and long sustained high income disparity can be blamed along within efficient public management for making the situation more severe in Africa. To track this here we consider two main elements of human development, namely, health and education to assess the impact of inequality on human development both under the presence and absence of government expenditure. For each human development component, we employ both stock and investment indicators.

For health we use two most widely accepted health status indicators, namely, life expectancy (LE) and infant mortality rate (IMR). To get the investment indicators of health we employ per capital government health expenditure (PCGHE). Similarly, for education we use school enrollment in primary (PSE) and secondary (SSE) as two stock variables, while government expenditure in education (GEE) is considered as investment indicator for education. It is to be noted that measure of income inequality in the form of Gini can be obtained from several sources. For instance, many empirical studies use Luxembourg Income Study (LIS) database or the World Income Inequality Database (WIID) to get the data on Gini. However, due to the lack of continuous and consistent inequality data over time, Firebaugh (2003) suggests to choose some alternative. In this respect following Solt (2009), here we rely on the Standardized World Income Inequality Database (SWIID). Note, as far as the Gini is concerned one can use both gross income Gini coefficient and the net income Gini coefficient, however, here we use the Gini index of gross income inequality (GINI) (Herzer \& Nunnenkemp, 2015).

The data set consists of cross-country observations for 31 selected African countries over the period 1980-2017 obtained from the data base of World Bank ${ }^{1}$ and Standardized World Income Inequality Database (SWIID) ${ }^{2}$. The descriptive statistics of the said variables are reported in Table 1, while cross-sectional graphical representations for health and education are illustrated in Figures 2 and 3, respectively.

Table 1. Descriptive statistics

\begin{tabular}{|l|l|l|l|l|l|l|l|}
\hline & LE & IMR & PCGHE & PSE & SSE & GEE & GI \\
\hline Mean & 53.21 & 82.54 & 34.52 & 85.02 & 28.91 & 4.00 & 45.39 \\
\hline
\end{tabular}

1 Available at: $\underline{\text { http://data.worldbank.org/data-catalog/world-development-indicators. }}$

${ }^{2}$ Available at:http://thedata.harvard.edu/dvn/dv/fsolt/faces/study/StudyPage.xhtml?studyId=36908. 


\begin{tabular}{|c|c|c|c|c|c|c|c|}
\hline Median & 52.57 & 79 & 9.13 & 87.09 & 22.83 & 3.50 & 43.41 \\
\hline Maximum & 74.39 & 174.5 & 325.17 & 152.21 & 102.75 & 44.33 & 69.34 \\
\hline Minimum & 27.61 & 11.6 & 1.31 & 17.29 & 2.48 & 1.03 & 23.64 \\
\hline Std. Dev. & 7.36 & 34.29 & 65.55 & 28.64 & 21.50 & 2.53 & 8.55 \\
\hline Skewness & 0.12 & 0.31 & 2.68 & -0.22 & 1.28 & 8.18 & 0.49 \\
\hline Kurtosis & 3.13 & 2.46 & 9.30 & 2.54 & 4.35 & 120.59 & 2.56 \\
\hline Jarque-Bera & 3.91 & 33.30 & 1390.08 & 17.15 & 274.52 & 18.15 & 31.15 \\
\hline Observations & 1147 & 1173 & 486 & 1028 & 784 & 564 & 641 \\
\hline \multicolumn{8}{|l|}{ Correlation } \\
\hline & LE & IMR & PCGHE & PSE & SSE & GEE & GINI \\
\hline LE & 1 & & & & & & \\
\hline IMR & -0.83 & 1 & & & & & \\
\hline PCGHE & 0.13 & -0.51 & 1 & & & & \\
\hline PSE & 0.28 & -0.43 & 0.21 & 1 & & & \\
\hline SSE & 0.36 & -0.70 & 0.80 & 0.38 & 1 & & \\
\hline GEE & 0.05 & -0.41 & 0.41 & 0.25 & 0.44 & 1 & \\
\hline GINI & -0.19 & -0.25 & 0.70 & 0.37 & 0.59 & 0.40 & 1 \\
\hline
\end{tabular}

Source: Authors' calculation.

Figure 2- Illustration of LE, IMR, PCGHE and GINI in African continent

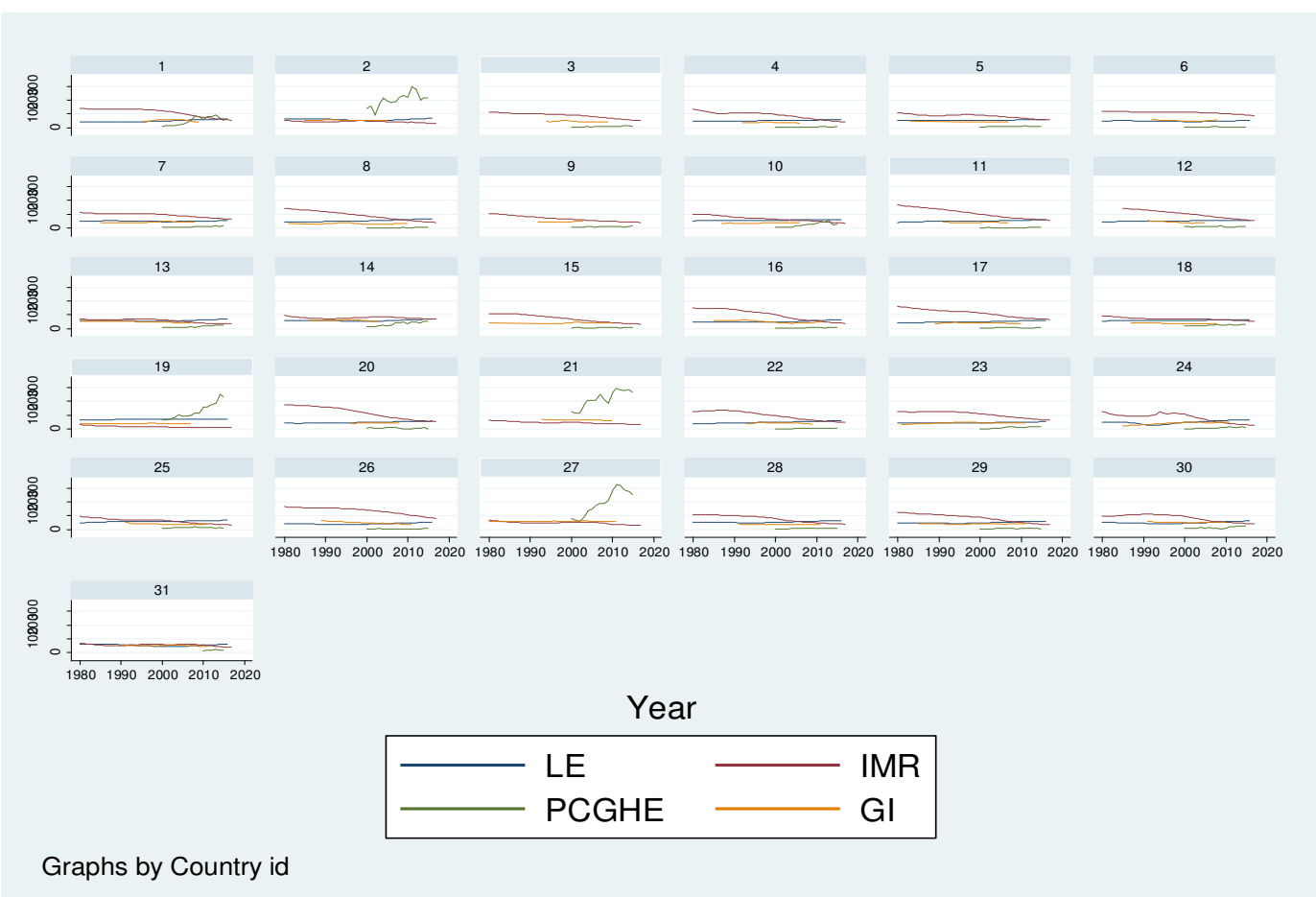

Note-Country id 1-31 stands for Angola, Botswana, Burkina Faso, Burundi, Cameroon, Central African Republic, Cote D'Ivoire, Ethiopia, Gambia, Ghana, Guinea, Guinea-Bissau, Kenya, Lesotho, Madagascar, Malawi, Mali, Mauritania, Mauritius, Mozambique, Namibia, Niger, Nigeria, Rwanda, Senegal, Sierra Leone, south Africa, Tanzania, Uganda, Zambia, Zimbabwe respectively. 
Figure 3- Illustration of PSE, SSE, GEE and GINI in African continent

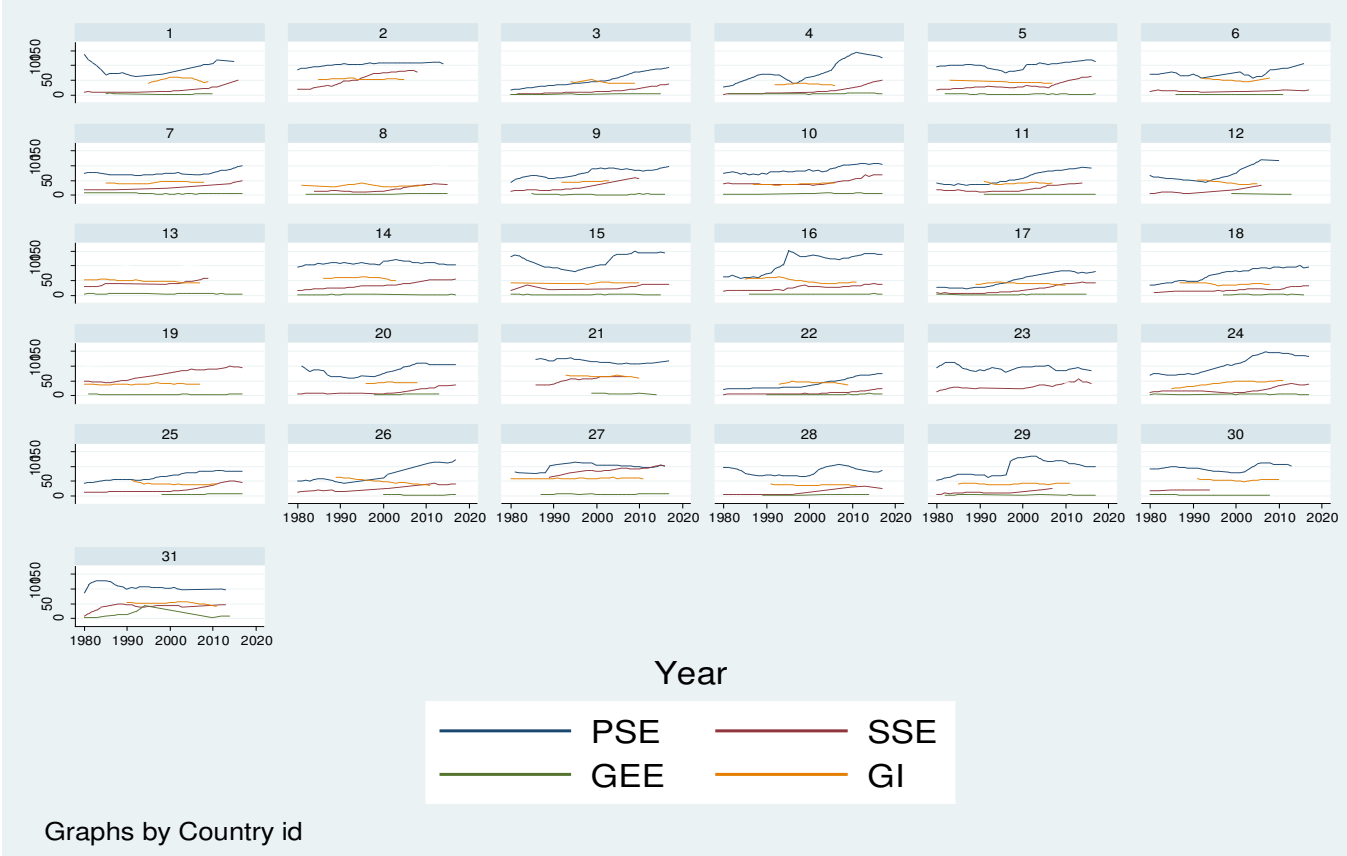

Note-Country id 1-31 stands for Angola, Botswana, Burkina Faso, Burundi, Cameroon, Central African Republic, Cote D'Ivoire, Ethiopia, Gambia, Ghana, Guinea, Guinea-Bissau, Kenya, Lesotho, Madagascar, Malawi, Mali, Mauritania, Mauritius, Mozambique, Namibia, Niger, Nigeria, Rwanda, Senegal, Sierra Leone, south Africa, Tanzania, Uganda, Zambia, Zimbabwe respectively.

\subsection{Estimation Strategy}

In the analysis of the long run relationship of panel data, the choice of the appropriate estimation technique is an important theoretical and empirical question. Thus, Cointegration is the most appropriate technique to study the long-term relationship between our health and inequality variables, as well as education and inequality measures. The empirical strategy used in this paper can be divided into four main stages. First, unit root tests of the panel series will be undertaken. Second, if they are integrated of the same order, the Co-integration tests will be used. Third, if the series are co-integrated, the panel vector error correction (PVECM) will be applied and following this both long-run and short-run causality shall be checked. Finally, as the time series are co-integrated with same order, the vector of Co-integration in the longterm will be estimated using the fully modified OLS and dynamic OLS methods.

\section{Panel unit roots}


To check the stationarity of each of the variables, we have employed proper diagnostic checks following several panel unit root tests. For a particular variable ' $y_{i, t}{ }^{\prime}$ where $\mathrm{i}=1$, $2, \ldots, \mathrm{N}$ and $t=1,2, \ldots, \mathrm{T}$, representing any one of the following panel variables, namely: LE, IMR, PSE, SSE, PCGHE, GEE and GINI, we can use ADF(p)(1979) unit root test, which is given by its linear regression form (equation 1 ). Here $\mathrm{N}=30$ and $\mathrm{T}=17$, where i denotes the number of cross-sections and $t$ denotes the number of periods included in our study.

$$
\Delta y_{i, t}=\left(\rho_{i}-1\right) y_{i, t-1}+\sum_{j=1}^{p} \gamma_{j} \Delta y_{i, t-j}+R_{i, t}^{\prime} \alpha_{i}+u_{i, t}
$$

Where, $R_{i, t}$ represents the vector of exogenous variables in the model, including any fixed effects or individual trends. The null hypothesis for this model is $\rho_{i}=1$ and the alternative hypothesis is $\rho_{i}<1$.

Advancing over the above-stated unit roots check Levin and Lin (1993) and Levin, Lin and Chu (2002) have proposed a variety of panel unit root tests owing to the assumption regarding the homogeneity of coefficients across cross-sections. Thus equation (9) can be restructured as,

$\Delta y_{i, t}=\rho y_{i, t-1}+\sum_{j=1}^{p} \gamma_{j} \Delta y_{i, t-j}+R_{i, t}^{\prime} \alpha_{i}+u_{i, t}$

Another line of view which assumes the presence heterogeneous coefficients across different cross-sections (Im, Pesaran \& Shin, 1997; Maddala \& Wu, 1999), has used the following form of panel unit root test statistic

$$
\chi^{2}=-2 \sum_{i=1}^{N}\left(\log p_{i}\right)
$$

\section{Panel Co-integration}

In applied econometrics, it is comprehensively acknowledged that the process of panel co-integration tests is a two-step rather that a single step approach. In the first step we have to culture the panel unit roots checks and if it ensures that the variables of our concern are non-stationary at levels but become stationary at their first difference or if they are integrated or order one I(1), then we can proceed to the second step where panel cointegration test can be performed. The African economies with which we shall deal the present econometric exercises are heterogeneous mainly due to differences in the degree of economic and development conditions. Therefore, panel cointegration test proposed by Pedroni $(1997,1999,2004)$ is adopted here, since this method Pedroni (2004) of panel co-integration based on residuals that takes the heterogeneity in individual cross-section effects, the slope coefficients and individual linear trends 
between cross-sections into account. Pedroni (2004) assumes the following regressions with and without intercept constant and trends, which are given by equations (12) and (13) below.

$$
\begin{aligned}
& y_{i, t}=\alpha_{i}+\partial_{i} \mathrm{t}+\beta_{i} x_{i, t}+u_{i, t} \\
& y_{i, t}=\beta_{i} x_{i, t}+u_{i, t}
\end{aligned}
$$

where, $y$ stands for either health (or education) and $x$ stands for GINI and PCGHE (or GEE). The $\beta_{i}$ slope coefficients are allowed to vary from one member to another, so in general, the co-integration vectors may be heterogeneous among the panel members. Pedroni (1997) proposes seven statistics to test the null hypothesis of no co-integration in heterogeneous panels. These tests comprise two sets of tests. The first one is withindimension test, which uses following four test statistics, namely, panel $v$-statistic, panel $\rho$-statistic, panel PP-statistic, and panel ADF-statistic, while, the second test group is based on the "between" dimension (the "Group") statistics, which uses following test statistics group $\rho$-statistic, group PP-statistic, and group ADF-statistic.

\section{Vector Error Correction Mechanism (VECM)}

Once we find that the relation among the variables of concern are in equilibrium in the long-run, we have to find out that whether the errors due to the short run deviations from the equilibrium relations are corrected and the series converge to the long run equilibrium or not. To test this, we introduce Vector error correction mechanism (VECM), where the cointegration term is termed as the error correction term.

Assuming equations (7) as our baseline association between LE (or IMR) and GINI, here, we represent the VECM model. To present the VECM we need to frame the following VAR structure -

$$
\begin{aligned}
& L E_{t}=\alpha_{1}+\sum_{J=1}^{n} \beta_{1 J} L E_{t-j}+\sum_{J=1}^{n} \gamma_{1 J} G I N I_{t-j}+u_{1 t} \\
& G I N I_{t}=\alpha_{2}+\sum_{J=1}^{n} \beta_{2 J} G I N I_{t-j}+\sum_{J=1}^{n} \gamma_{2 J} L E_{t-j}+u_{2 t} \\
& I M R_{t}=\alpha_{3}+\sum_{J=1}^{n} \beta_{3 J} L E_{t-j}+\sum_{J=1}^{n} \gamma_{3 J} G I N I_{t-j}+u_{3 t} \\
& G I N I_{t}=\alpha_{4}+\sum_{J=1}^{n} \beta_{4 J} G I_{N-j}+\sum_{J=1}^{n} \gamma_{4 J} L E_{t-j}+u_{4 t}
\end{aligned}
$$


Similarly, assuming equations (8) as our baseline association between PSE (or SSE) and GINI, here, we represent the VECM model. To present the VECM in this case we need to frame the following VAR structure -

$$
\begin{aligned}
& P S E_{t}=\alpha_{5}+\sum_{J=1}^{n} \beta_{5 J} P S E_{t-j}+\sum_{J=1}^{n} \gamma_{5 J} \operatorname{GINI}_{t-j}+u_{5 t} \\
& G I N I_{t}=\alpha_{6}+\sum_{J=1}^{n} \beta_{6 J} \operatorname{GINI}_{t-j}+\sum_{J=1}^{n} \gamma_{6 J} P S E_{t-j}+u_{6 t} \\
& S S E_{t}=\alpha_{7}+\sum_{J=1}^{n} \beta_{7 J} S S E_{t-j}+\sum_{J=1}^{n} \gamma_{7 J} \operatorname{GINI}_{t-j}+u_{7 t} \\
& \operatorname{GINI}_{t}=\alpha_{8}+\sum_{J=1}^{n} \beta_{8 J} \operatorname{GINI}_{t-j}+\sum_{J=1}^{n} \gamma_{8 J} S S E_{t-j}+u_{8 t}
\end{aligned}
$$

Where, $a, \beta, \gamma$ stand for the intercept and slope coefficients under different cases.

If we assume that the optimum lag is 2 then the values of $j$ will be 1 and 2 , the two represented variables (i.e., $\mathrm{x}$ and $\mathrm{y}$ ) are related by one cointegrating equation and no lagged difference terms. The cointegrating equation for no intercept and trend is given by the following equation:

$x_{t}=\beta y_{t}$

Therefore, the estimated error term in first difference is given as-

$$
\varepsilon_{t-1}=x_{t-1}-\beta y_{t-1}
$$

Therefore, the corresponding PVECM is

$$
\begin{aligned}
& \Delta x_{t}=\alpha_{y}\left(x_{t-1}-\beta y_{t-1}\right)+e_{x} \\
& \Delta y_{t}=\alpha_{x}\left(y_{t-1}-\beta x_{t-1}\right)+e_{y}
\end{aligned}
$$

Here only right-hand side variables are the error correction (EC) terms which are zero in the long run equilibrium. However, if ' $y$ ' and ' $x$ ' deviate from the long run equilibrium, the error correction terms will be non-zero and each variable adjusts to partially restore the equilibrium relation. The coefficient ' $a$ ' measures the speed of adjustment of the $i^{\text {th }}$ endogenous variable towards the equilibrium.

Now the PVECM is set by including the terms $\alpha_{y}\left(x_{t-1}-\beta y_{t-1}\right)$ into equations (14, or 16, or 18 , or 20$)$ and $(15$, or 17 , or 19 , or 21$)$ as additional explanatory variables. If the error correction terms are found to be negative and statistically significant then we say that the short term errors are corrected and the series are back to the long run equilibrium. Moreover, it is also inferred that there is long run causality from ' $y$ ' to ' $x$ ' or vice versa. 
Finally, the short run causality can also be captured in this PVECM set up by applying Wald test.

\section{Estimation of long run cointegrating relationship}

Following the confirmation of the existence of long run cointegrating relationship between the variables, it must be followed by the estimation of the long-run coefficients. Various techniques are available to estimate the long run coefficients among a vector of cointegration panel data, including with and between groups. These include panel OLS, Fully Modified OLS (FMOLS) and dynamic OLS (DOLS) techniques. However, as shown by Wagner and Hlouskova (2010), the result of panel DOLS estimators outperform other asymptotically efficient panel cointegration estimators and they are more efficient. Despite this fact, we have reported the estimation outcomes of both FMOLS and DOLS to judge the robustness of our study. The DOLS regression can be represented as

$$
y_{i, t}=\alpha_{i}+\partial_{i} \mathrm{t}+\beta x_{i, t}+\sum_{j=-k}^{k} \theta_{i, j} \Delta x_{i, t-j}+u_{i, t}
$$

Where, $\Delta$ is the difference operator and $k$ is the number of leads and lags.

Finally, to check the robustness of several causal relations with which we are interested, we employ both impulse response function (IRF) and forecast variance decomposition method (FEVDM). As both these methods provide the course and scale of causal connotations between model parameters at various temporal frames and illustrate relative strength causal associations also (Shahbaz, 2012; Tiwari and Shahbaz, 2014).

\subsection{Estimation specification}

Following the theoretical arguments (i.e., in terms of equation (7)) and African facts we shall estimate the following specifications to separately examine the presence of significant income inequality to curb both health status and education status in the selected African countries. Thus, we estimate the following equations (equations 26 through 28) to examine the health status

$$
\begin{aligned}
& \text { Health }_{i t}=\alpha_{i}+\delta_{i} t+\beta G I N I_{i t}+\varepsilon_{i t} \\
& \text { Health }_{i t}=\alpha_{i}+\delta_{i} t+\beta G I N I_{i t}+\gamma P C G H E_{i t}+\varepsilon_{i t} \\
& \text { Health }_{i t}=\alpha_{i}+\delta_{i} t+\beta G I N I_{i t}+\gamma P C G H E_{i t}+\lambda P C G H E_{i t} * G I N I_{i t}+\varepsilon_{i t}
\end{aligned}
$$


Where, $\alpha_{i}$ are country specific fixed effects, $\delta_{i} t$ are country-specific time trends, Healt $h_{i t}$ refer to the health status of cross-section i's population in time $t$. Following the standard literature, either life expectancy at birth or infant mortality rate is used to measure population health status. Equation (28) shows a non-linear specification of equation (27) and it includes an interaction between PCGHE and GINI as an additional explanatory variable in order to find the optimal threshold value of public health expenditure. This can be obtained by differentiating equation (28) with respect to GINI.

$$
\frac{\partial \text { Health }_{i t}}{\partial G I N I_{i t}}=\beta+\lambda P C G H E_{i t}
$$

Equation(13) allows us to compute the marginal effect of income inequality on health status with respect to public health expenditure. Moreover, following equation (7) and right panel of Figure 1, expression (29) can determine the threshold value of public health expenditure that allows positive relationship between inequality and health status.

Similar to that of health, we shall estimate the following equations for education status as well (following equation (8)).

$$
\begin{aligned}
& \text { Education }_{i t}=\alpha_{i}+\delta_{i} t+\beta G I N I_{i t}+\varepsilon_{i t} \\
& \text { Education }_{i t}=\alpha_{i}+\delta_{i} t+\beta G I N I_{i t}+\gamma G E E_{i t}+\varepsilon_{i t} \\
& \text { Education }_{i t}=\alpha_{i}+\delta_{i} t+\beta G I N I_{i t}+\gamma G E E_{i t}+\lambda G E E_{i t} * G I N I_{i t}+\varepsilon_{i t}
\end{aligned}
$$

Where, Education $_{i t}$ refers to the education status of cross-section $i$ 's population in time $t$. Following the standard literature, either PSE or SSE is used to measure population education status. Equation (32) shows a non-linear specification of equation (31) and it includes an interaction between GEE and GINI as an additional independent variable to find the optimal threshold value of public education expenditure. This can be obtained by differentiating equation (32) with respect to GINI.

$$
\frac{\partial \text { Education }_{i t}}{\partial G I N I_{i t}}=\beta+\lambda G E E_{i t}
$$


Equation (33) allows us to compute the marginal effect of inequality on health status with respect to public health expenditure. We can also determine the threshold value of public education expenditure that allows positive relationship between inequality and education status.

\section{Empirical Results and Discussion}

Here, we begin with a diagnostic test to check the presence of multicollinearity in the data. To do so we have engaged with Variance Inflation Factor (VIF) analysis. The outcomes are reported in Table A.1 (in the Appendix) and it shows that all variables are free from multicollinearity. Next, we perform another diagnostic test to check crosssectional dependency in the model and the results are reported in Table A.2 in the Appendix. As the result of Table A.2 shows that the variables are not cross-sectionally dependent and hence, we can proceed with first-generation methods to analyse longrun association among the variables of interest. To check the long run association between health status and income inequality, and education status with income inequality in the selected African countries, we started with stationarity tests among the relevant variables following the Levin, Lin and Chu (LLC) test, Im, Pesaran and Shin (IPS) test, the augmented Dickey-Fuller (ADF) test, and Phillips-Perron-Fisher chisquare (PP) test. Table 2 depicts the result of these tests and shows that all the variables are non stationary at levels, but becomes stationary at first difference, or they are integrated of order one $(\mathrm{I}(1)$ ), and hence raises the possibilities of long run associations among them.

Table-2 Panel unit root tests

\begin{tabular}{|l|l|l|l|l|l|l|l|l|}
\hline & \multicolumn{3}{|c|}{ At level } & At first difference \\
\hline Variable & IPS test & LLC test & ADF test & PP test & IPS test & LLC test & ADF test & PP test \\
\hline LE & 8.63 & 8.18 & 7.06 & 4.25 & -9.35 & -22.09 & 1132.32 & 102.97 \\
& $(0.99)$ & $(1.00)$ & $(1.00)$ & $(1.00)$ & $(0.00)^{*}$ & $(0.00)^{*}$ & $(0.00)^{*}$ & $(0.00)^{*}$ \\
\hline IMR & -0.88 & 7.03 & 24.64 & 61.15 & -7.12 & -6.80 & 179.15 & 98.15 \\
& $(0.18)$ & $(1.00)$ & $(0.32)$ & $(0.50)$ & $(0.00)$ & $(0.00)$ & $(0.00)$ & $(0.00)$ \\
\hline PSE & 3.54 & 0.89 & 53.48 & 49.32 & -12.44 & -11.02 & 295.23 & 333.60 \\
& $(0.99)$ & $(0.81)$ & $(0.77)$ & $(0.87)$ & $(0.00) *$ & $(0.00)^{*}$ & $(0.00)^{*}$ & $(0.00)^{*}$ \\
\hline SSE & 10.43 & 6.92 & 30.11 & 28.05 & -10.64 & -16.91 & 202.17 & 232.59 \\
& $(1.00)$ & $(1.00)$ & $(0.99)$ & $(0.99)$ & $(0.00)$ & $(0.00)$ & $(0.00)$ & $(0.00)$ \\
\hline PCGHE & 0.29 & 3.60 & 64.97 & 49.29 & -13.32 & -14.52 & 280.24 & 356.78 \\
& $(0.61)$ & $(0.98)$ & $(0.37)$ & $(0.87)$ & $(0.00) *$ & $(0.00)^{*}$ & $(0.00)^{*}$ & $(0.00)^{*}$ \\
\hline GEE & -0.19 & -0.15 & 40.67 & 48.76 & -9.32 & -13.05 & 208.83 & 321.58 \\
& $(0.42)$ & $(0.44)$ & $(0.97)$ & $(0.84)$ & $(0.00)$ & $(0.00)$ & $(0.00)$ & $(0.00)$ \\
\hline GINI & 0.43 & 4.12 & 76.21 & 72.96 & -5.88 & -4.63 & 152.15 & 155.25 \\
& $(0.66)$ & $(1.00)$ & $(0.10)$ & $(0.16)$ & $(0.00) *$ & $(0.00)^{*}$ & $(0.00)^{*}$ & $(0.00)^{*}$ \\
\hline
\end{tabular}


Note-This table reports the test statistics followed by the probability values in parentheses for the four stationarity tests performed. $\left({ }^{*}\right)$ shows statistical significance at $1 \%$ level.

Tables 3, 4, 5 and 6 show the outcomes of panel cointegration test statistics of both within and between dimensions of the panel dataset. These statistics are based on averages of the individual autoregressive coefficients associated with the unit root tests of the residuals for each country in the panel. These results suggest the presence of long run cointegrating relationships between health status (LE or IMR) and income inequality. Moreover, our result shows the existence of long run relationships between income inequality and education status (PSE or SSE) in the selected African countries. Tables 3A and 4A further report that both IMR and LE are associated with inequality and public expenditure on health in the selected African countries. Similarly, tables 5A and table 6A further reveal long run associations between different education indicators with inequality and government expenditure in Africa ${ }^{3}$.

Table 3. Pedroni residual panel cointegration test for LE and GINI

\begin{tabular}{|c|c|c|c|c|}
\hline Hypotheses $\rightarrow$ & \multicolumn{2}{|c|}{ Null Hypothesis: No Cointegration } & Statistic & Weighted \\
\hline \multirow{7}{*}{$\begin{array}{l}\text { No } \\
\text { deterministic } \\
\text { trend }\end{array}$} & \multirow{4}{*}{$\begin{array}{l}\text { Alternative hypothesis: } \\
\text { common AR coefficients } \\
\text { (within-dimension) }\end{array}$} & Panel v-Statistic & $0.71(0.26)$ & $0.68(0.23)$ \\
\hline & & Panel rho-Statistic & $-5.14(0.00)$ & $-5.21(0.00)$ \\
\hline & & Panel PP-Statistic & $-6.17(0.00)$ & $-6.06(0.00)$ \\
\hline & & Panel ADF-Statistic & $-5.07(0.00)$ & $-5.01(0.00)$ \\
\hline & \multirow{3}{*}{$\begin{array}{l}\text { Alternative hypothesis: } \\
\text { individual AR coefficients } \\
\text { (between-dimension) }\end{array}$} & Group rho-Statistic & $-2.38(0.01)$ & - \\
\hline & & Group PP-Statistic & $-4.89(0.00)$ & - \\
\hline & & Group ADF-Statistic & $-4.59(0.00)$ & - \\
\hline \multirow{7}{*}{$\begin{array}{l}\text { Deterministic } \\
\text { intercept and } \\
\text { trend }\end{array}$} & \multirow{4}{*}{$\begin{array}{l}\text { Alternative hypothesis: } \\
\text { common AR coefficients } \\
\text { (within-dimension) }\end{array}$} & Panel v-Statistic & $-1.06(0.99)$ & $-1.67(0.99)$ \\
\hline & & Panel rho-Statistic & $-4.25(0.00)$ & $-3.75(0.00)$ \\
\hline & & Panel PP-Statistic & $-6.02(0.00)$ & $-5.31(0.00)$ \\
\hline & & Panel ADF-Statistic & $-3.91(0.00)$ & $-4.09(0.00)$ \\
\hline & \multirow{3}{*}{$\begin{array}{l}\text { Alternative hypothesis: } \\
\text { individual AR coefficients } \\
\text { (between-dimension) }\end{array}$} & Group rho-Statistic & $-0.57(0.29)$ & - \\
\hline & & Group PP-Statistic & $-4.87(0.00)$ & - \\
\hline & & Group ADF-Statistic & $-4.71(0.00)$ & - \\
\hline \multirow{7}{*}{$\begin{array}{l}\text { No } \\
\text { deterministic } \\
\text { intercept and } \\
\text { trend }\end{array}$} & \multirow{4}{*}{$\begin{array}{l}\text { Alternative hypothesis: } \\
\text { common AR coefficients } \\
\text { (within-dimension) }\end{array}$} & Panel v-Statistic & $2.25(0.01)$ & $0.55(0.39)$ \\
\hline & & Panel rho-Statistic & $-6.93(0.00)$ & $-3.15(0.00)$ \\
\hline & & Panel PP-Statistic & $-6.55(0.00)$ & $-3.07(0.00)$ \\
\hline & & Panel ADF-Statistic & $-3.78(0.00)$ & $-2.45(0.01)$ \\
\hline & \multirow{3}{*}{$\begin{array}{l}\text { Alternative hypothesis: } \\
\text { individual AR coefficients } \\
\text { (between-dimension) }\end{array}$} & Group rho-Statistic & $-2.15(0.01)$ & - \\
\hline & & Group PP-Statistic & $-4.05(0.00)$ & - \\
\hline & & Group ADF-Statistic & $-4.88(0.00)$ & - \\
\hline
\end{tabular}

Source: Computed by the authors and the bold figures indicate significant cointegration results.

\footnotetext{
${ }^{3}$ Note, results of tables $3 \mathrm{~A}, 4 \mathrm{~A}, 5 \mathrm{~A}$ and $6 \mathrm{~A}$ are reported in the Appendix.
} 
Table 4. Pedroni residual panel cointegration testfor IMR and GINI

\begin{tabular}{|c|c|c|c|c|}
\hline & \multicolumn{2}{|c|}{ Null Hypothesis: No Cointegration } & Statistic (Prob) & Weighted \\
\hline \multirow{7}{*}{$\begin{array}{l}\text { No } \\
\text { deterministic } \\
\text { trend }\end{array}$} & \multirow{4}{*}{$\begin{array}{l}\text { Alternative hypothesis: } \\
\text { common AR } \\
\text { coefficients (within- } \\
\text { dimension) }\end{array}$} & Panel v-Statistic & $0.90(0.18)$ & $-0.07(0.53)$ \\
\hline & & Panel rho-Statistic & $0.77(0.78)$ & $-2.19(0.01)$ \\
\hline & & Panel PP-Statistic & $-0.21(0.41)$ & $-3.63(0.00)$ \\
\hline & & Panel ADF-Statistic & $-1.97(0.03)$ & $-4.29(0.00)$ \\
\hline & \multirow{3}{*}{$\begin{array}{l}\text { Alternative hypothesis: } \\
\text { individual AR } \\
\text { coefficients (between- } \\
\text { dimension) }\end{array}$} & Group rho-Statistic & $-3.66(0.00)$ & - \\
\hline & & Group PP-Statistic & $-0.56(0.27)$ & - \\
\hline & & $\begin{array}{l}\text { Group ADF- } \\
\text { Statistic }\end{array}$ & $-2.06(0.02)$ & - \\
\hline \multirow{7}{*}{$\begin{array}{l}\text { Deterministic } \\
\text { intercept and } \\
\text { trend }\end{array}$} & \multirow{4}{*}{$\begin{array}{l}\text { Alternative hypothesis: } \\
\text { common AR } \\
\text { coefficients (within- } \\
\text { dimension) }\end{array}$} & Panel v-Statistic & $6.09(0.00)$ & $-1.93(0.03)$ \\
\hline & & Panel rho-Statistic & $-2.42(0.01)$ & $-0.12(0.45)$ \\
\hline & & Panel PP-Statistic & $-7.61(0.00)$ & $-1.89(0.03)$ \\
\hline & & Panel ADF-Statistic & $-3.72(0.00)$ & $-1.45(0.08)$ \\
\hline & \multirow{3}{*}{$\begin{array}{l}\text { Alternative hypothesis: } \\
\text { individual AR } \\
\text { coefficients (between- } \\
\text { dimension) }\end{array}$} & Group rho-Statistic & $0.75(0.77)$ & - \\
\hline & & Group PP-Statistic & $-2.36(0.00)$ & - \\
\hline & & $\begin{array}{l}\text { Group ADF- } \\
\text { Statistic }\end{array}$ & $-1.21(0.13)$ & - \\
\hline \multirow{7}{*}{$\begin{array}{l}\text { No } \\
\text { deterministic } \\
\text { intercept and } \\
\text { trend }\end{array}$} & \multirow{4}{*}{$\begin{array}{l}\text { Alternative hypothesis: } \\
\text { common AR } \\
\text { coefficients (within- } \\
\text { dimension) }\end{array}$} & Panel v-Statistic & $2.38(0.01)]$ & $-0.94(0.82)$ \\
\hline & & Panel rho-Statistic & $-0.62(0.26)$ & $-3.50(0.00)$ \\
\hline & & Panel PP-Statistic & $-1.82(0.03)$ & $-0.48(0.32)$ \\
\hline & & Panel ADF-Statistic & $-3.08(0.00)]$ & $-5.70(0.00)$ \\
\hline & \multirow{3}{*}{$\begin{array}{l}\text { Alternative hypothesis: } \\
\text { individual AR } \\
\text { coefficients (between- } \\
\text { dimension) }\end{array}$} & Group rho-Statistic & $-0.69(0.24)$ & - \\
\hline & & Group PP-Statistic & $-3.82(0.00)$ & - \\
\hline & & $\begin{array}{l}\text { Group ADF- } \\
\text { Statistic }\end{array}$ & $-2.83(0.01)$ & - \\
\hline
\end{tabular}

Note: Computed by the authors and the bold figures indicate significant cointegration results.

Table 5. Pedroni residual panel cointegration test for PSE and GINI

\begin{tabular}{|c|c|c|c|c|}
\hline Hypotheses $\rightarrow$ & \multicolumn{2}{|c|}{ Null Hypothesis: No Cointegration } & Statistic & Weighted \\
\hline \multirow{7}{*}{$\begin{array}{l}\text { No } \\
\text { deterministic } \\
\text { trend }\end{array}$} & \multirow{4}{*}{$\begin{array}{l}\text { Alternative hypothesis: } \\
\text { common AR coefficients } \\
\text { (within-dimension) }\end{array}$} & Panel v-Statistic & $0.56(0.36)$ & $0.61(0.25)$ \\
\hline & & Panel rho-Statistic & $-3.34(0.00)$ & $-5.01(0.00)$ \\
\hline & & Panel PP-Statistic & $-8.17(0.00)$ & $-6.76(0.00)$ \\
\hline & & Panel ADF-Statistic & $-0.59(0.38)$ & $-5.01(0.00)$ \\
\hline & \multirow{3}{*}{$\begin{array}{l}\text { Alternative hypothesis: } \\
\text { individual AR coefficients } \\
\text { (between-dimension) }\end{array}$} & Group rho-Statistic & $-2.38(0.01)$ & - \\
\hline & & Group PP-Statistic & $-4.89(0.00)$ & - \\
\hline & & Group ADF-Statistic & $-1.79(0.08)$ & - \\
\hline \multirow{5}{*}{ Deterministic } & \multirow{4}{*}{$\begin{array}{l}\text { Alternative hypothesis: } \\
\text { common AR coefficients } \\
\text { (within-dimension) }\end{array}$} & Panel v-Statistic & $-3.06(0.00)$ & $-2.67(0.01)$ \\
\hline & & Panel rho-Statistic & $-4.25(0.00)$ & $-3.75(0.00)$ \\
\hline & & Panel PP-Statistic & $-1.06(0.99)$ & $-1.67(0.99)$ \\
\hline & & Panel ADF-Statistic & $-3.61(0.00)$ & $-3.09(0.00)$ \\
\hline & Alternative hypothesis: & Group rho-Statistic & $-0.67(0.27)$ & - \\
\hline
\end{tabular}




\begin{tabular}{|c|c|c|c|c|}
\hline \multirow{2}{*}{$\begin{array}{l}\text { intercept and } \\
\text { trend }\end{array}$} & \multirow{2}{*}{$\begin{array}{l}\text { individual AR coefficients } \\
\text { (between-dimension) }\end{array}$} & Group PP-Statistic & $-7.67(0.00)$ & - \\
\hline & & Group ADF-Statistic & $-0.71(0.21)$ & - \\
\hline \multirow{7}{*}{$\begin{array}{l}\text { No } \\
\text { deterministic } \\
\text { intercept and } \\
\text { trend }\end{array}$} & \multirow{4}{*}{$\begin{array}{l}\text { Alternative hypothesis: } \\
\text { common AR coefficients } \\
\text { (within-dimension) }\end{array}$} & Panel v-Statistic & $2.05(0.02)$ & $0.55(0.39)$ \\
\hline & & Panel rho-Statistic & $-8.23(0.00)$ & $-3.95(0.00)$ \\
\hline & & Panel PP-Statistic & $-6.55(0.00)$ & $-4.17(0.00)$ \\
\hline & & Panel ADF-Statistic & $-3.78(0.00)$ & $-2.61(0.01)$ \\
\hline & \multirow{3}{*}{$\begin{array}{l}\text { Alternative hypothesis: } \\
\text { individual AR coefficients } \\
\text { (between-dimension) }\end{array}$} & Group rho-Statistic & $-0.15(0.48)$ & - \\
\hline & & Group PP-Statistic & $-2.05(0.02)$ & - \\
\hline & & Group ADF-Statistic & $-6.08(0.00)$ & - \\
\hline
\end{tabular}

Source: Computed by the authors and the bold figures indicate significant cointegration results.

Table 6. Pedroni residual panel cointegration test for SSE and GINI

\begin{tabular}{|c|c|c|c|c|}
\hline $\begin{array}{l}\text { Hypotheses } \rightarrow \\
\text { / Test Criteria } \downarrow\end{array}$ & \multicolumn{2}{|c|}{ Null Hypothesis: No Cointegration } & Statistic (Prob) & $\begin{array}{c}\text { Weighted } \\
\text { Statistic (Prob) }\end{array}$ \\
\hline \multirow{7}{*}{$\begin{array}{l}\text { No } \\
\text { deterministic } \\
\text { trend }\end{array}$} & \multirow{4}{*}{$\begin{array}{l}\text { Alternative hypothesis: } \\
\text { common AR } \\
\text { coefficients (within- } \\
\text { dimension) } \\
\end{array}$} & Panel v-Statistic & $0.71(0.13)$ & $-0.57(0.33)$ \\
\hline & & Panel rho-Statistic & $4.77(0.00)$ & $-0.79(0.29)$ \\
\hline & & Panel PP-Statistic & $-0.21(0.41)$ & $-1.63(0.07)$ \\
\hline & & Panel ADF-Statistic & $-7.97(0.00)$ & $-4.29(0.00)$ \\
\hline & \multirow{3}{*}{$\begin{array}{l}\text { Alternative hypothesis: } \\
\text { individual AR } \\
\text { coefficients (between- } \\
\text { dimension) }\end{array}$} & Group rho-Statistic & $-3.46(0.00)$ & - \\
\hline & & Group PP-Statistic & $-4.56(0.00)$ & - \\
\hline & & $\begin{array}{l}\text { Group ADF- } \\
\text { Statistic }\end{array}$ & $-0.86(0.25)$ & - \\
\hline \multirow{7}{*}{$\begin{array}{l}\text { Deterministic } \\
\text { intercept and } \\
\quad \text { trend }\end{array}$} & \multirow{4}{*}{$\begin{array}{l}\text { Alternative hypothesis: } \\
\text { common AR } \\
\text { coefficients (within- } \\
\text { dimension) }\end{array}$} & Panel v-Statistic & $0.69(0.31)$ & $-1.89(0.03)$ \\
\hline & & Panel rho-Statistic & $-2.31(0.01)$ & $-0.82(0.18)$ \\
\hline & & Panel PP-Statistic & $-4.61(0.00)$ & $-1.99(0.02)$ \\
\hline & & Panel ADF-Statistic & $-7.72(0.00)$ & $-1.51(0.07)$ \\
\hline & \multirow{3}{*}{$\begin{array}{l}\text { Alternative hypothesis: } \\
\text { individual AR } \\
\text { coefficients (between- } \\
\text { dimension) }\end{array}$} & Group rho-Statistic & $0.75(0.77)$ & - \\
\hline & & Group PP-Statistic & $-4.36(0.00)$ & - \\
\hline & & $\begin{array}{l}\text { Group ADF- } \\
\text { Statistic }\end{array}$ & $-1.01(0.21)$ & - \\
\hline \multirow{7}{*}{$\begin{array}{l}\text { No } \\
\text { deterministic } \\
\text { intercept and } \\
\text { trend }\end{array}$} & \multirow{4}{*}{$\begin{array}{c}\text { Alternative hypothesis: } \\
\text { common AR } \\
\text { coefficients (within- } \\
\text { dimension) }\end{array}$} & Panel v-Statistic & $2.18(0.01)$ & $-3.94(0.00)$ \\
\hline & & Panel rho-Statistic & $-0.69(0.31)$ & $-7.50(0.00)$ \\
\hline & & Panel PP-Statistic & $-2.82(0.01)$ & $-0.78(0.30)$ \\
\hline & & Panel ADF-Statistic & $-4.08(0.00)$ & $-0.71(0.29)$ \\
\hline & \multirow{3}{*}{$\begin{array}{l}\text { Alternative hypothesis: } \\
\text { individual AR } \\
\text { coefficients (between- } \\
\text { dimension) }\end{array}$} & Group rho-Statistic & $-0.69(0.24)$ & - \\
\hline & & Group PP-Statistic & $-4.12(0.00)$ & - \\
\hline & & $\begin{array}{l}\text { Group ADF- } \\
\text { Statistic }\end{array}$ & $-3.73(0.00)$ & - \\
\hline
\end{tabular}

Note: Computed by the authors and the bold figures indicate significant cointegration results.

Alternatively, we have also tested the Kao and Fisher-Johansen tests for cointegration to make our analysis more robust. Tables (7) and (8) illustrate the outcomes Kao and Fisher-Johansen tests. Both the tests suggest that all the twelve relations of our interest are associated in long-run run. 
Table 7. Kao residual cointegration test

\begin{tabular}{ccc}
\hline \multicolumn{3}{c}{ ADF with Null Hypothesis: No cointegration } \\
\hline Variables & t-Statistic & Prob. \\
LE \& GINI & -1.81 & 0.04 \\
IMR \&GINI & -1.59 & 0.05 \\
PSE \& GINI & -1.85 & 0.04 \\
SSE \& GINI & -1.57 & 0.05 \\
\hline
\end{tabular}

Source: Computed by the authors

Table 8.Fisher-Johansen cointegration test

\begin{tabular}{cccccc}
\hline & & Fisher Stat. & \multicolumn{1}{c}{ Fisher Stat. } & \\
\hline Variables & & (from trace test) & Prob. & (from max-eigen test) & Prob. \\
LE \& GINI & None & 97.3 & 0.00 & 101.89 & 0.00 \\
& At most 1 & 57.4 & 0.00 & 49.38 & 0.00 \\
IMR \& GINI & None & 71.3 & 0.00 & 93.3 & 0.00 \\
& At most 1 & 47.4 & 0.01 & 49.13 & 0.01 \\
PSE \& GINI & None & 79.1 & 0.00 & 97.01 & 0.00 \\
& At most 1 & 41.9 & 0.01 & 57.03 & 0.00 \\
SSE \&GINI & None & 67.3 & 0.00 & 83.5 & 0.00 \\
& At most 1 & 57.4 & 0.01 & 51.19 & 0.00 \\
\hline
\end{tabular}

Source: Computed by the authors

Hence, all the three cointegration test results for the panel of selected African countries show that there is clear evidence of the existence of long run equilibrium association between health and income inequality, and also for education and income inequality during the period of the study.

From cointegration test outcomes we find that health (LE and IMR) and education (PSE and SSE) are associated with GINI in long run at least in case of our panel. Here we further examine the vector error correction to see the dynamics after deviations from the equilibrium relations and the outcomes of the panel VECM are shown in Table 9. It is to be noted that here we run the panel VECM only for the said four relations and reports the same in Table 9. Moreover, following AIC and SIC we have found lag 3 as the optimum lag for the said four relations.

Table 9. Panel VECM results for the selected African Countries

\begin{tabular}{ccccc}
\hline $\begin{array}{c}\text { Dependent } \\
\text { Variables }\end{array}$ & EC terms & Probability & $\begin{array}{c}\text { Whether errors } \\
\text { corrected }\end{array}$ & Remarks \\
\hline $\mathbf{D}($ LE) & $\mathbf{- 0 . 4 0 8}$ & $\mathbf{0 . 0 2}$ & Yes & $\begin{array}{c}\text { Long run causality from } \\
\text { GINI to LE }\end{array}$ \\
$\mathbf{D}$ (GINI) & -0.010 & 0.18 & No & $\begin{array}{c}\text { No long run causality from } \\
\text { LE to GINI }\end{array}$ \\
D(IMR) & $\mathbf{- 0 . 1 4 9}$ & $\mathbf{0 . 0 5}$ & Yes & $\begin{array}{c}\text { Long run causality from } \\
\text { GINI to IMR }\end{array}$ \\
$\mathbf{D}$ (GINI) & -0.001 & 0.33 & No & $\begin{array}{c}\text { No long run causality from } \\
\text { IMR to GINI }\end{array}$ \\
\hline
\end{tabular}




\begin{tabular}{ccccc}
\hline D(PSE) & $\mathbf{- 0 . 0 0 5}$ & $\mathbf{0 . 0 7}$ & Yes & $\begin{array}{c}\text { Long run causality from } \\
\text { GINI to PSE }\end{array}$ \\
D(GINI) & -0.75 & 0.43 & No & $\begin{array}{c}\text { No long run causality from } \\
\text { PSE to GINI }\end{array}$ \\
D(SSE) & $\mathbf{- 0 . 0 1 8}$ & $\mathbf{0 . 0 3}$ & Yes & $\begin{array}{c}\text { Long run causality from } \\
\text { GINI to SSE }\end{array}$ \\
D(GINI) & 0.912 & 0.57 & No & $\begin{array}{c}\text { No long run causality from } \\
\text { SSE to GINI }\end{array}$ \\
\hline
\end{tabular}

Source: Computed by the authors

It is observed that the EC terms for the LE, IMR, PSE and SSE being the dependent variables are of desired negative sign and statistically significant but the result for GINI as the dependent variable is not statistically significant, although it is negative, except the case of GINI with SSE. This leads us to conclude that the errors are corrected in the case when LE, IMR, PSE and SSE are the dependent variable and further it shows that there are long run causal effects from GINI to health (in terms of LE, IMR) and education (in terms of PSE and SSE) in case of selected African countries.

Table 10 shows the outcomes short-run causality between Health and GINI, and Education and GINI in selected African countries. The test for short run interplays in the panel by means of Wald test shows some interesting results. It shows that even there are significant unilateral causal relations from GINI and LE (or IMR) to LE (or IMR), however, bilateral causal relations from all the past values of GINI and PSE (or SSE) to PSE (or SSE) and all the past values of GINI and PSE (or SSE) to GINI.

Table 10. Short run causality between LE (or IMR, or PSE, or SSE) and GINI

\begin{tabular}{|c|c|c|c|c|}
\hline Dependent Variable & Chi square & Prob. & Remarks & \\
\hline D(LE) & 9.38 & 0.04 & $\begin{array}{l}\text { All past values of LE and GINI } \rightarrow \text { LE } \\
\text { of the current period }\end{array}$ & \multirow{2}{*}{$\begin{array}{l}\text { Unilateral causality } \\
\text { from GINI to LE in } \\
\text { the short run }\end{array}$} \\
\hline D(GINI) & 2.07 & 0.18 & $\begin{array}{c}\text { No short-run causality from All past } \\
\text { values of LE and GINI } \rightarrow \text { GINI of the } \\
\text { current period }\end{array}$ & \\
\hline D(IMR) & 11.71 & 0.02 & $\begin{array}{l}\text { All past values of LE and GINI } \rightarrow \text { LE } \\
\text { of the current period }\end{array}$ & \multirow{2}{*}{$\begin{array}{l}\text { Unilateral causality } \\
\text { from GINI to IMR in } \\
\text { the short run }\end{array}$} \\
\hline D(GINI) & 0.97 & 0.28 & $\begin{array}{l}\text { No short-run causality from All past } \\
\text { values of LE and GINI } \rightarrow \text { GINI of the } \\
\text { current period }\end{array}$ & \\
\hline D(PSE) & 10.07 & 0.03 & $\begin{array}{l}\text { All past values of PSE and } \\
\text { GINI } \rightarrow \text { PSE of the current period }\end{array}$ & \multirow{2}{*}{$\begin{array}{l}\text { Bilateral causality } \\
\text { between PSE and } \\
\text { GINI in the short run }\end{array}$} \\
\hline D(GINI) & 36.27 & 0.00 & $\begin{array}{l}\text { All past values of PSE and } \\
\text { GINI } \rightarrow \text { GINI of the current period }\end{array}$ & \\
\hline D(SSE) & 11.01 & 0.02 & $\begin{array}{l}\text { All past values of SSE and } \\
\text { GINI } \rightarrow \text { SSE of the current period }\end{array}$ & \multirow{2}{*}{$\begin{array}{c}\text { Bilateral causality } \\
\text { between R\&D ratio } \\
\text { and FDI ratio in the } \\
\text { short run }\end{array}$} \\
\hline D(GINI) & 29.27 & 0.00 & $\begin{array}{l}\text { All past values of SSE and } \\
\text { GINI } \rightarrow \text { GINI of the current period }\end{array}$ & \\
\hline
\end{tabular}

Source: Computed by the authors 
Therefore, the panel data results unambiguously establish that Education status and GINI for the group of African countries as a whole are cointegrated and there are both way causal relations between the two variables in the short-run, while in the long-run the causality is running from GINI to education only. Again, similar to the case of education, Health status and GINI for the same panel are also cointegrated and shows one way causation from GINI to Health in long-run. However, unlike the case of education here, the one way causation from GINI to Health is hold also in short-run. Hence, the panel of selected African countries requires more stringent policies either to control income inequality or to boost up presence of state in terms government expenditure (in health and education) to offset the adverse effect of inequality in major social sectors like health and education in Africa. In this study we focus mainly on the second policy element, that is, betterment of health and education through government investment.

To estimate the long run coefficients of the above stated probable long run associations, DOLS technique is used. Moreover, FMOLS technique is also employed to verify the robustness of our results. Tables (11), (12), (13) and (14) depict the outcomes of DOLS and FMOLS techniques for dependent variables like LE, IMR, PSE and SSE respectively.

Table- 11 Estimates of the long-run effect of GINI and PCGHE on LE in African countries

\begin{tabular}{|c|c|c|c|c|c|c|}
\hline $\begin{array}{l}\text { Independent } \\
\text { variables }\end{array}$ & (1) & (2) & (3) & (4) & (5) & (6) \\
\hline GINI & $\begin{array}{c}-0.13^{*} \\
(-4.60)\end{array}$ & $\begin{array}{l}-0.36^{*} \\
(-4.69)\end{array}$ & $\begin{array}{l}1.17 * \\
(48.59)\end{array}$ & $\begin{array}{c}-0.01^{*} \\
(-2.71)\end{array}$ & $\begin{array}{l}-0.22^{*} \\
(-25.84)\end{array}$ & $\begin{array}{l}1.19^{*} \\
(46.35)\end{array}$ \\
\hline PCGHE & & $\begin{array}{l}0.008 \\
(0.85)\end{array}$ & $\begin{array}{l}0.83 * \\
(6.40)\end{array}$ & & $\begin{array}{l}0.01 * \\
(17.93)\end{array}$ & $\begin{array}{l}0.83 * \\
(6.26)\end{array}$ \\
\hline PCGHE*GINI & & & $\begin{array}{l}-0.015^{*} \\
(-7.04)\end{array}$ & & & $\begin{array}{l}-0.01 * \\
(-6.85)\end{array}$ \\
\hline Fixed effects & Yes & Yes & Yes & Yes & Yes & Yes \\
\hline Individual Trend & Yes & Yes & Yes & Yes & Yes & Yes \\
\hline DOLS & Yes & Yes & Yes & No & No & No \\
\hline FMOLS & No & No & No & Yes & Yes & Yes \\
\hline Countries & 31 & 16 & 31 & 31 & 29 & 30 \\
\hline Observations & 539 & 133 & 285 & 604 & 250 & 253 \\
\hline \multicolumn{7}{|c|}{$\begin{array}{l}\text { Note- The dependent variable is LE and t-statistics are in parenthesis. }{ }^{* *}\left({ }^{* *}\right)\left[{ }^{*}\right] \text { indicate significance at } \\
\text { the ten (five) [one] percent levels, respectively. The DOLS results are based on a one lead/lag model. } \\
\text { Table- } 12 \text { Estimates of the long-run effect of GINI and PCGHE on IMR in African } \\
\text { countries }\end{array}$} \\
\hline $\begin{array}{l}\text { Independent } \\
\text { variables }\end{array}$ & (1) & (2) & (3) & (4) & (5) & (6) \\
\hline
\end{tabular}




\begin{tabular}{lllllll}
\hline GINI & $0.82^{*}$ & $1.08^{*}$ & $0.79^{* *}$ & $0.97^{*}$ & $\begin{array}{l}1.14^{*} \\
(3.14)\end{array}$ & $\begin{array}{l}0.76^{* * *} \\
(1.83)\end{array}$ \\
& $(3.58)$ & $(2.96)$ & $(2.16)$ & $(4.15)$ & $-0.10^{*}$ & $-0.72^{* *}$ \\
PCGHE & & $-0.09^{*}$ & $-0.58^{* * *}$ & & $(-2.70)$ & $0.03^{* * *}$ \\
& & $(-2.35)$ & $(-1.69)$ & & & $(1.88)$ \\
PCGHE*GINI & & & $0.02^{* *}$ & & & \\
& & & $(1.98)$ & & & Yes \\
Fixed effects & Yes & Yes & Yes & Yes & Yes & Yes \\
Individual Trend & Yes & Yes & Yes & Yes & No & No \\
DOLS & Yes & Yes & Yes & No & Yes & Yes \\
FMOLS & No & No & No & Yes & 30 & 30 \\
Countries & 31 & 31 & 31 & 31 & 253 & 253 \\
\hline Observations & 641 & 285 & 285 & 604 & 253 \\
\hline
\end{tabular}

Note- The dependent variable is IMR and t-statistics are in parenthesis. ${ }^{* * *}\left({ }^{* *}\right)\left[{ }^{*}\right]$ indicate significance at the ten (five) [one] percent levels, respectively. The DOLS results are based on a one lead/lag model.

Columns (1) and (4) of tables (11) and (12) illustrate adverse impact of income disparity on health status in the selected African countries. The estimated coefficients are negative and statistically significant at one percent level. It shows that GINI is responsible for about 0.01 to 0.13 basis fall in life expectancy, while such disparity explain 0.82 to 0.97 basis increase in infant mortality in the selected African countries. This result is consistent with earlier empirical works of Rodgers (1979), Flegg (1982) and Waldmann (1992). To make the matter more quantitative, we multiply the coefficient of GINI (-0.13) in column (1) of table (11) with the average change in the GINI index $(0.056)$ and $365(-0.13 \times 0.056 \times 365=2.65)$ and it reveals that the average loss of life expectancy due to inequality is about 2.65 days per year for the African countries. Interestingly this loss is quite high compared to the estimated loss of 1.48 daysfor developing countries shown by Herzer and Nunnenkemp (2015).It seems that the adverse effect of inequality on health status is not only adverse in Africa but the impact is much severe relative to other developing countries. To look into the matter more precisely, we include PCGHE as an additional independent variable and the estimated coefficients are reported in columns (2) and (5) of tables (11) and (12), and they are statistically significant at a desired level. It shows that GINI is responsible for about 0.22 to 0.36 basis fall in life expectancy, while such disparity explains 1.08 to 1.14 basis increase in infant mortality in our sample. Same estimation also tells us about the positive impact of government expenditure on health status of African countries, however, the effectiveness of such expenditure is very low in magnitude, say PCGHE can increase LE only by 0.01 (column (5) of table (11)). Moreover, the average loss of life expectancy due to inequality is about 7.35 days per year for African countries, which is quite high. It shows, poor or inefficient state health management is responsible for further degradation of health status in Africa. To make this analysis more policy oriented, we introduce the interaction between GINI and PCGHE as an additional 
independent variable and make the relationship non-linear. Columns (3) and (6) of tables (11) and (12) shows that the interaction variable has negative (or positive) and statistically significant effect on LE (or IMR), respectively. Subsequently, column (3) of table (11) (or table (12)) and equation (29) show that 117 US dollar (or 39.5 US dollar) of PCGHE is required as threshold for improvement in LE (or IMR) in the presence of income inequality. The result shows that only four nations, namely, Botswana, Mauritius, Namibia and South Africa among the selected African countries are efficiently managed their public health expenditure to promote health status at least in terms of LE.

Table- 13 Estimates of the long-run effect of GINI and GEE on PSE in African countries

\begin{tabular}{lllllll}
\hline $\begin{array}{l}\text { Independent } \\
\text { variables }\end{array}$ & $(\mathbf{1})$ & $\mathbf{( 2 )}$ & $\mathbf{( 3 )}$ & $\mathbf{( 4 )}$ & $\mathbf{( 5 )}$ & $\mathbf{( 6 )}$ \\
\hline GINI & $-0.36^{* *}$ & $-1.62^{*}$ & $1.64^{*}$ & $-1.90^{*}$ & $-1.47^{*}$ & $1.56^{*}$ \\
& $(-2.09)$ & $(-15.70)$ & $(16.71)$ & $(-48.49)$ & $(-10.49)$ & $(10.77)$ \\
GEE & & $-3.30^{*}$ & $11.64^{*}$ & & $-5.41^{*}$ & $12.50^{*}$ \\
& & $(-3.06)$ & $(4.66)$ & & $(-3.44)$ & $(4.26)$ \\
GEE*GINI & & $-0.17^{*}$ & & & $-0.17^{*}$ \\
& & $(-3.65)$ & & & $(-2.79)$ \\
Fixed effects & Yes & Yes & Yes & Yes & Yes & Yes \\
Individual Trend & Yes & Yes & Yes & Yes & Yes & Yes \\
DOLS & Yes & Yes & Yes & No & No & No \\
FMOLS & No & No & No & Yes & Yes & Yes \\
Countries & 31 & 29 & 29 & 31 & 26 & 24 \\
Observations & 560 & 279 & 279 & 527 & 194 & 190 \\
\hline
\end{tabular}

Note- The dependent variable is PSE and t-statistics are in parenthesis. ${ }^{* * *}\left({ }^{* *}\right)\left[{ }^{*}\right]$ indicate significance at ten (five) [one] percent levels, respectively. The DOLS results are based on a one lead/lag model.

Table- 14 Estimates of the long-run effect of GINI and GEE on SSE in African countries

\begin{tabular}{|c|c|c|c|c|c|c|}
\hline $\begin{array}{l}\text { Independent } \\
\text { variables }\end{array}$ & (1) & (2) & (3) & (4) & (5) & (6) \\
\hline GINI & $\begin{array}{l}-0.28^{*} \\
(-5.62)\end{array}$ & $\begin{array}{l}3.45^{*} \\
(5.76)\end{array}$ & $\begin{array}{l}9.65^{* *} \\
(2.19)\end{array}$ & $\begin{array}{l}-0.70^{*} \\
(-21.96)\end{array}$ & $\begin{array}{l}0.31 * * \\
(1.97)\end{array}$ & $\begin{array}{l}0.16^{* *} \\
(1.97)\end{array}$ \\
\hline GEE & & $\begin{array}{l}-22.54 * \\
(-3.45)\end{array}$ & $\begin{array}{l}-0.88^{* *} \\
(-3.68)\end{array}$ & & $\begin{array}{l}-5.90 * \\
(-3.48)\end{array}$ & $\begin{array}{l}-0.08 * * * \\
(-1.76)\end{array}$ \\
\hline GEE*GINI & & & $\begin{array}{l}-0.16 * * * \\
(-1.88)\end{array}$ & & & $\begin{array}{l}-0.15^{*} \\
(-2.79)\end{array}$ \\
\hline Fixed effects & Yes & Yes & Yes & Yes & Yes & Yes \\
\hline Individual Trend & Yes & Yes & Yes & Yes & Yes & Yes \\
\hline DOLS & Yes & Yes & Yes & No & No & No \\
\hline FMOLS & No & No & No & Yes & Yes & Yes \\
\hline Countries & 26 & 24 & 24 & 31 & 26 & 27 \\
\hline Observations & 315 & 307 & 307 & 367 & 314 & 312 \\
\hline
\end{tabular}


Columns (1) and (4) of tables (13) and (14) illustrate the adverse impact of income disparity on education status in the selected African countries. The estimated coefficients are negative and statistically significant at the one percent level. They show that GINI is responsible for about 0.36 to 1.90 basis fall in PSE, while such disparity explains 0.28 to 0.70 basis rise in SSE in Africa. Similar to that of health, in case of education status, we have included GEE as an additional independent variable, in order to examine the efficiency of public expenditure in education. The results of the estimation with GEE are reported in columns (2) and (5) of tables (13) and (14), and the estimated coefficients are significant at the one percent level. These results suggest almost the same conclusion regarding the effect of GINI on education status, however, the exercise claims negative effect of GEE on education. In fact, it shows that PSE (SSE) declines by 3.30 to 5.41 (5.90 to 22.54) basis point owing to an increase in GEE. Such findings are consistent with previous empirical works of Knowles \& Owen (1995) and Li\& Huang (2010), however, differ from those of McDonald and Roberts (2002) and Ram (2007) who suggest that development oriented policies support investment in education over health. To make this analysis more policy oriented we have introduced the interaction between GINI and GEE as a new independent variable and make the relationship non-linear. Columns (3) and (6) of tables (13) and (14) suggest that the coefficient of the interaction variable is negative and significant for both PSE and SSE in the selected African economies. Consequently, column (3) of table (13) and equation (33) tell us that 9.64 US dollar GEE is required as threshold for the betterment of primary education in Africa. However, the need of GEE in secondary education has increased almost seven times of what is needed at the primary level, that is, for SSE the threshold value of GEE reach to 60.31 US dollar. Most strikingly, none of African countries of our sample are reached near of these education statistics.

Table A.3 illustrates the outcomes of variance decomposition analysis with 20-year forecasting horizons. Up to ten years, income inequality is responsible for almost $7 \%$ and almost $1 \%$ variance in life expectancy and infant mortality in Africa, where as public spending in health is contributing much less compared to inequality. However, after ten years the scenario has changed and the contribution of public spending on health increased by $8 \%$ in case of life expectancy and $4 \%$ in case of infant mortality. Similarly for education after ten years, public spending on education is responsible for almost $8 \%$ variance in both PSE and SSE in Africa. It shows that though in short time frame (for instance, 10 years) income inequality is contribution higher variance on both education and health compared to public spending, however, in long time frame (for instance 20 years) the contribution of public spending dominates over the inequality. The results of IRF also describe the same in terms of Figure A.1 and A.2. 


\section{Conclusion}

\subsection{Summary of Results and assumptions}

This study represents an attempt to address the nexus between Health and income inequality, and Education and income inequality using a panel dataset for 31 African countries over the period of 1980-2017. By establishing the long-run association between the variables of our interest via cointegration, we have cleared the path of the application of panel vector error correction model. From such set up it is revealed that health inequality affects both health and education adversely in both long-run and short-run in Africa. To make the analysis more policy oriented for African continent, here we have incorporated the role of state in the form public expenditure in both health and education as additional control variables. Interestingly for the same panel, we have again established the cointegration among health, inequality and public expenditure in health, and education, inequality and public expenditure in education. Finally, by applying the DOLS (and FMOLS) we have found that in long-run even though income inequality adversely affects both health and education in Africa, however, positive environment for both health and education can be refueled with government will. In fact, for each case we have derived the required or threshold level of state intervention for better health and education in African continent.

\subsection{Policy Recommendations and caveats}

Our empirical analysis suggests that in short-run government of our selected African countries must adopt stimulating developmental packages to boost education to avoid vicious circle of poor education trap (that is, income inequality to poor education to low productivity to low production to income inequality). Our theory suggests that a big push in the form of large volume of government spending in education sector is quite necessary in long-run to eject from just-mentioned trap. For health related concern, our empirical study argues in favour of government spending in health to improve health status in the selected African countries. Moreover, policymakers of these nations must adopt efficient poverty and income inequality alleviation programs to better off in both education and health. In short, policymakers of these nations must consider poverty and inequality programs (may be in terms of income transfer from rich to poor) and public spending as complement not as substitute.

\subsection{Limitations of the Study and Future Research Agendas}

First, Non-linear causality and non-linear long run association can be taken to analyse the non-linear perspective. Second, gini inequality measures can be taken from other 
alternative sources. Third, private investment can also be considered in the place of public investment. However, these will be in our future research agendas.

\section{Declarations}

Availability of data and materials

Data and materials used in this study are available in following links- 1. : http:// data.worldbank.org/data-catalog/world-development-indicators

2.

http://thedata.harvard.edu/dvn/dv/fsolt/faces/study/StudyPage.xhtml?studyId=36908.

Competing interests

No potential competing interests is reported by the authors.

Funding

The authors declare that they received no specific funding for this work.

Authors' contributions

Both the authors developed theoretical framework, designed and performed computation, analyzed the data, interpreted the results, and wrote the manuscript.

Acknowledgements

Not applicable

\section{References}

Aisa, R., \& Pueyo, F. (2006). Government health spending and growth in a model of endogenous longevity. Economics Letters, 90, (2), 249-253.

Alesina, A., Baqir, R., \& Easterly, W. (1999). Public Goods and Ethnic Divisions. Quarterly Journal of Economics, 114(4), 1243-1284.

Anderson, E., D'Orey, M. A. J., Duvendack, M., \& Esposito, L. (2017). Does government spending affect income inequality? A meta-regression analysis, Journal of economic surveys, 31(4), 1-27.

Banerjee, A. V., \& Newman, A. F. (1993). Occupational Choice and the Process of Development. Journal of Political Economy, 101(2), 274-298.

Becker, G. (1964). Human Capital. New York: Columbia University Press for the National Bureau of Economic Research.

Bourdieu, P., \& Passeron, J. C. (1990). Reproduction in Education, Society and Culture. transl. R. Nice, Newbury Park, CA: Sage, (From French).

Cavelaars, A.E.J.M., Kunst, A. E., Geurts, J. J. M., Crialesi, R., Grötvedt, L., Helmert, U., Lahelma, E., Lundberg, O., Matheson, J., Mielck, A., et al. (1998). Differences in selfreported morbidity by educational level: A comparison of 11 Western European countries. J Epidemiol Community Health,52, 219-27. 
Cervellati, M., \& Sunde, U. (2005). Human Capital, Life Expectancy, and the Process of Development. American Economic Review, 95(5), 1653-1672.

Checchi, D. (2003). Inequality in Incomes and Access to Education. A Cross-country Analysis (1960-95). Labour, 17(2), 153-201.

Claus, I., Martinez-Vazquez, J., \& Vulovic, V. (2012). Government fiscal policies and redistribution in Asian countries. ADB Economics Working Paper Series 310, Manila: Asian Development Bank.

Dahl, E., Fritzell, J., Lahelma, E., Martikainen, P., Kunst, A., \& Mackenbach, J. P. (2006). Welfare regimes and health inequalities. In: Siegrist J, Marmot $\mathrm{M}$, editors. Social Inequalities in health: New Evidence and Policy Implications, pp.193-222, Oxford: Oxford University Press.

Deaton, A. (2003). Health, Inequality, and Economic Development. Journal of Economic Literature, 41(1), 113-158.

Eggoh, J., Houeninvo, H., \& Sossou, G. (2015). Education, Health and Economic Growth in African Countries. Journal of Economic Development, 40, (1), 93-111.

Eikemo, T. A., Bambra, C., Joyce, K., \& Dahl, E. (2008). Welfare state regimes and income related health inequalities: a comparison of 23 European countries. Eur J Pub Health, 18,593-9.

EU. (2012). Literature review on income inequality and the effects on social outcomes. European Commission, Joint Research Centre, Institute for IPSC. Italy.

Filmer, D., \& Pritchett, L. (1999). The Effect of Household Wealth on Educational Attainment: Evidence from 35 Countries. Population and Development Review, 25(1), 85120.

Flug, K., Spilimbergo, A., \& Wachtenheim, E. (1998). Investment in Education: Do Economic Volatility and Credit Constraints Matter? Journal of Development Economics, 55(2), 465-481.

Galor, O., \& Zeira, J. (1993). Income Distribution and Macroeconomics. Review of Economic Studies, 60(1), 35-52.

Gerth, H., Mills, C. .W, eds. (1946). From Max Weber: Essays in Sociology. New York: Oxford Univ. Press 
Gravelle, H. (1998). How Much of the Relation Between Population Mortality and Unequal Distribution of Income is a Statistical Artifact? British Medical Journal, 316, 382385.

Grodsky, E., \& Jackson, E. (2009). Social stratification in higher education. Teach. Coll. Rec., 111, 2347-84.

Herzer, H., \& Nunnenkemp, P. (2015). Income Inequality and Health: Evidence from Developed and Developing Countries. Economics, 9(4), 1-56.

Hoffmann, R. (2011). Socioeconomic inequalities in old-age mortality: A comparison of Denmark and the USA. Soc Sci Med, 72, 1986-92.

Hoffmann, R., Hu, Y., de Gelder, R., Menvielle, G., Bopp, M., \& Mackenbach, J.P. (2016). The impact of increasing income inequalities on educational inequalities in mortality An analysis of six European countries. International Journal for Equity in Health, 15, 103.

Hout, M. (2012). Social and economic returns to college education in the United States. Annu. Rev. Sociol., 38, 379-400.

Leigh, A., \& Jencks, C. (2007). Inequality and mortality: Long-run evidence from a panel of countries. Journal of Health Economics, 26(1), 1-24.

Leigh, A., Jencks, C., \& Smeeding, T. M. (2009). Health and Economic Inequality. In W. Salverda, B. Nolan, \& T. Smeeding, The Oxford Handbook of Economic Inequality, 384405, Oxford: Oxford University Press.

Lopez-Casasnovas, G., Costa-Font, J., \& Planas, I. (2005). Diversity and regional inequalities in the Spanish 'system of health care services'. Health Econ., 14, S221S235. https://doi.org/10.1002/hec.1038

Lynch, J., Smith, G. D., Harper, S., Hillemeier, M., Ross, N., Kaplan, G. A., et al. (2004). Is Income Inequality a Determinant of Population Health? Part 1. A Systematic Review. Milbank Quarterly, 82(1), 5-99.

Mackenbach, J. P., Kunst, A. E., Cavelaars, A. E. J. M., Groenhof, F., \& Geurts, J. J. M. (1997). Socioeconomic inequalities in morbidity and mortality in western Europe. The EU Working Group on Socioeconomic Inequalities in Health. Lancet,349,1655-9.

Mackenbach, J. P., Stirbu, I., Roskam, A. J. R., Schaap, M. M., Menvielle, G., Leinsalu, M., \& Kunst, A. E. (2008). Socioeconomic inequalities in health in 22 European countries. N Engl J Med.,358, 2468-81. 
Maddala, G., \& Wu, S. (1999). A comparative study of unit root tests with panel data and a new simple test. Oxford Bulletin of Economics and Statistics, 61(S1), 631-652.

Mirowsky, J., \& Ross, C. E. (2003). Education, Social Status, and Health. New York: Aldine de Gruyter.

Nash, R. (1990). Bourdieu on education and social and cultural reproduction. Br. J. Sociol. Educ., 11, 431-47.

Pedroni, P. (1999). Critical values for cointegration tests in heterogeneous panels with multiple regressors. Oxford Bulletin of Economics and Statistics, 61(Special Issue Nov.), 653-670.

Pedroni, P. (2004). Panel cointegration: Asymptotic and finite sample properties of pooled time series tests with an application to the PPP hypothesis. Econometric Theory, 20(3), 597-625.

Perotti, R. (1996). Growth, Income Distribution and Democracy: What the Data Say. Journal of Economic Growth, 1(2), 149-187.

Pickett, K.E., \& Wilkinson, R.G. (2015). Income inequality and health: A causal review. Social Science \& Medicine, 128, 316-326.

Preston, S. H. (1975). The changing relation between mortality and level of economic development. Population Studies, 29(2), 231-248.

Romer, P.M. (1990). Endogenous Technological Change. Journal of Political Economy, 98(5), S71-S102.

Ray, D., \& Linden, M. (2018). Health, inequality and income: a global study using simultaneous model. Economic Structures, 7, 22. https://doi.org/10.1186/s40008-018$\underline{0121-3}$

Ross, N. A., Wolfson, M. C., Dunn, J. R., Berthelot, J. M., Kaplan, G. A., \& Lynch, J. W. (2000). Relation between income inequality and mortality in Canada and in the United States: Cross sectional assessment using census data and vital statistics, BMJ, 320, 898902.

Saha, L. J. (2008). Sociology of education. In 21st Century Education: A Reference Handbook, ed. TL Good, 299-307. Thousand Oaks, CA: Sage. 
Shahbaz, M. (2012). Does trade openness affect long run growth? Cointegration, causality and forecast error variance decomposition tests for Pakistan. Economic Modelling, 29(6), 2325-2339.

Sapolsky, R.M. (2004). Social status and health in humans and other animals. Annual Review of Anthropology, 33, 393-418.

Schultz, T. (1963). Economic value of education. Columbia university press, New York. Stevens, M. L., Armstrong, E. A., Arum, R. (2008). Sieve, incubator, temple, hub: empirical and theoretical advances in the sociology of higher education. Annu. Rev. Sociol, 34, 127-51.

Stevens, M. L., Armstrong, E. A., \& Arum, R. (2008). Sieve, Incubator, Temple, Hub: Empirical and Theoretical Advances in the Sociology of Higher Education. Annual Review of Sociology, 34(1), 127-151.

Tiwari, A. K., \& Shahbaz, M. (2014). Revisiting purchasing power parity for India using threshold cointegration and nonlinear unit root test. Economic Change and Restructuring, 47(2), 117-133.

Topel, R. H. (1997). Factor Proportions and Relative Wages: The Supply-Side Determinants of Wage Inequality. Journal of Economic Perspectives, 11(2), 55-74.

Van Doorslaer, E., \& Koolman, X. (2004). Explaining the differences in income-related health inequalities across European countries. Health Econ.,13, 609-28.

Walsemann, K. M., Gee, G. C., \& Ro, A. (2013). Educational attainment in the context of social inequality: new directions for research on education and health. Am. Behav. Sci., 57, 1082-104.

Wilkinson, R. G. (1992). Income distribution and life expectancy. British Medical Journal, 304(6820), 165-168.

Wilkinson, R. G. (1997). Income, inequality and social cohesion. American Journal of Public Health, 87, 104-106.

Wilkinson, R.G. (2000). Mind the Gap: Hierarchies, health, and human evolution. London: Weidenfeld and Nicolson.

Wilkinson, R., \& Pickett, K. (2006). Income inequality and population health: a review and explanation of the evidence. Social Science \& Medicine, 62, 1768-1784. 


\section{Appendix}

Table A.1- Multicollinearity statistics

\begin{tabular}{llll}
\hline Variables & VIF & Tolerance & R-square \\
\hline LE & 1.56 & 0.59 & 0.31 \\
GINI & 1.21 & 0.71 & 0.25 \\
PCGHE & 1.29 & 0.69 & 0.25 \\
& & & \\
IMR & 1.45 & 0.65 & 0.32 \\
GINI & 1.18 & 0.75 & 0.23 \\
PCGHE & 1.78 & 0.53 & 0.38 \\
& & & \\
PSE & 1.62 & 0.63 & 0.33 \\
GINI & 1.28 & 0.76 & 0.22 \\
GEE & 1.33 & 0.71 & 0.26 \\
& & & \\
SSE & 1.58 & 0.60 & 0.39 \\
GINI & 1.89 & 0.51 & 0.45 \\
GEE & 1.55 & 0.56 & 0.38 \\
\hline
\end{tabular}

Table- A.2 Cross-sectional dependence outcomes

\begin{tabular}{lll}
\hline Vriables & Statistics & p-value \\
\hline LE & 0.19 & 0.41 \\
GINI & 0.51 & 0.19 \\
PCGHE & 1.35 & 0.65 \\
& & \\
IMR & 0.15 & 0.31 \\
GINI & 0.16 & 0.18 \\
PCGHE & 0.62 & 0.35 \\
& & \\
PSE & 1.48 & 0.23 \\
GINI & 0.58 & 0.31 \\
GEE & 1.35 & 0.64 \\
& & \\
SSE & 0.61 & 0.35 \\
GINI & 0.43 & 0.15 \\
GEE & 1.67 & 0.28 \\
\hline
\end{tabular}

Table A.3 Variance Decomposition Analysis

\begin{tabular}{lcccc}
\hline Period & S. E. & LE & GINI & PCGHE \\
\hline $\mathbf{1}$ & 0.082379 & 100.0000 & 0.000000 & 0.000000 \\
\hline
\end{tabular}




\begin{tabular}{|c|c|c|c|c|}
\hline 2 & 0.178746 & 99.71086 & 0.080499 & 0.208642 \\
\hline 3 & 0.291517 & 98.63588 & 1.201608 & 0.162510 \\
\hline 4 & 0.417667 & 96.66678 & 3.315231 & 0.017986 \\
\hline 5 & 0.555957 & 93.77255 & 4.396646 & 1.830806 \\
\hline 6 & 0.706314 & 89.98318 & 8.434806 & 1.582012 \\
\hline 7 & 0.869482 & 85.38364 & 12.428825 & 2.18754 \\
\hline 8 & 0.706314 & 89.98318 & 7.434806 & 2.582012 \\
\hline 9 & 0.869482 & 85.38364 & 10.428825 & 4.18754 \\
\hline 10 & 1.451099 & 96.37311 & 1.456300 & 2.170593 \\
\hline 11 & 1.682280 & 95.92497 & 0.409041 & 3.665992 \\
\hline 12 & 1.935768 & 95.44469 & 0.371552 & 4.183759 \\
\hline 13 & 2.213787 & 94.93568 & 0.341865 & 4.722455 \\
\hline 14 & 2.518502 & 94.40087 & 0.318314 & 5.280813 \\
\hline 15 & 2.851994 & 93.84278 & 0.299510 & 5.857713 \\
\hline 16 & 3.216250 & 93.26353 & 0.284314 & 6.452156 \\
\hline 17 & 3.613161 & 92.66495 & 0.271802 & 7.063250 \\
\hline 18 & 4.044538 & 92.04857 & 0.261236 & 7.690190 \\
\hline 19 & 4.512123 & 91.41572 & 0.252032 & 8.332245 \\
\hline 20 & 5.017617 & 90.76752 & 0.243738 & 8.988741 \\
\hline Period & S E & IMR & GINI & PCGHE \\
\hline 1 & 0.517006 & 100.0000 & 0.000000 & 0.000000 \\
\hline 2 & 1.097597 & 99.82529 & 0.030566 & 0.144143 \\
\hline 3 & 1.745655 & 99.66110 & 0.066484 & 0.272413 \\
\hline 4 & 2.429216 & 99.52201 & 0.084335 & 0.393658 \\
\hline 5 & 3.126662 & 99.40233 & 0.083783 & 0.513885 \\
\hline 6 & 3.822880 & 99.29067 & 0.071331 & 0.637998 \\
\hline 7 & 4.507128 & 99.17564 & 0.054833 & 0.769528 \\
\hline 8 & 5.171780 & 99.04703 & 0.041697 & 0.911272 \\
\hline 9 & 5.811530 & 98.89591 & 0.038443 & 1.065651 \\
\hline 10 & 6.422841 & 98.71438 & 0.050722 & 1.234903 \\
\hline 11 & 7.003557 & 98.49535 & 0.083453 & 1.421200 \\
\hline 12 & 7.552604 & 98.23232 & 0.140968 & 1.626714 \\
\hline 13 & 8.069766 & 97.91922 & 0.227120 & 1.853656 \\
\hline 14 & 8.555502 & 97.55034 & 0.345366 & 2.104296 \\
\hline 15 & 9.010807 & 97.12022 & 0.498808 & 2.380970 \\
\hline 16 & 9.437089 & 96.62371 & 0.690211 & 2.686084 \\
\hline 17 & 9.836075 & 96.05589 & 0.922007 & 3.022100 \\
\hline 18 & 10.20973 & 95.41220 & 1.196276 & 3.391529 \\
\hline 19 & 10.56019 & 94.68837 & 1.514724 & 3.796905 \\
\hline 20 & 10.88970 & 93.88058 & 1.878648 & 4.240767 \\
\hline Period & S E & PSE & GINI & GEE \\
\hline 1 & 4.048150 & 100.0000 & 0.000000 & 0.000000 \\
\hline 2 & 6.249651 & 99.78986 & 0.017295 & 0.192849 \\
\hline 3 & 7.873182 & 99.80256 & 0.056473 & 0.140969 \\
\hline 4 & 9.153112 & 99.76476 & 0.113144 & 0.122097 \\
\hline 5 & 10.21081 & 99.60475 & 0.181728 & 0.213518 \\
\hline 6 & 11.11308 & 99.31900 & 0.256712 & 0.424289 \\
\hline 7 & 11.89952 & 98.92388 & 0.333298 & 0.742825 \\
\hline 8 & 12.59536 & 98.44054 & 0.407621 & 1.151837 \\
\hline 9 & 13.21766 & 97.88994 & 0.476753 & 1.633305 \\
\hline 10 & 13.77854 & 97.29110 & 0.538620 & 2.170275 \\
\hline 11 & 14.28695 & 96.66061 & 0.591890 & 2.747503 \\
\hline 12 & 14.74976 & 96.01249 & 0.635862 & 3.351644 \\
\hline 13 & 15.17237 & 95.35841 & 0.670350 & 3.971240 \\
\hline
\end{tabular}




\begin{tabular}{lcccc}
\hline $\mathbf{1 4}$ & 15.55916 & 94.70782 & 0.695587 & 4.596595 \\
$\mathbf{1 5}$ & 15.91373 & 94.06824 & 0.712136 & 5.219626 \\
$\mathbf{1 6}$ & 16.23917 & 93.44551 & 0.720815 & 5.833680 \\
$\mathbf{1 7}$ & 16.53812 & 92.84400 & 0.722632 & 6.433368 \\
$\mathbf{1 8}$ & 16.81289 & 92.26687 & 0.718727 & 7.014400 \\
$\mathbf{1 9}$ & 17.06554 & 91.71624 & 0.710333 & 7.573430 \\
$\mathbf{2 0}$ & 17.29792 & 91.19334 & 0.698730 & 8.107926 \\
$\mathbf{4 e r i o d}$ & $\mathbf{S ~ E}$ & & & \\
$\mathbf{1}$ & 1.804594 & $\mathbf{S S E}$ & $\mathbf{G I N I}$ & $\mathbf{G E E}$ \\
$\mathbf{2}$ & 2.632440 & 98.0000 & 0.000000 & 0.000000 \\
$\mathbf{3}$ & 3.236962 & 98.29509 & 0.225550 & 1.250738 \\
$\mathbf{4}$ & 3.764703 & 98.16057 & 0.488559 & 1.216353 \\
$\mathbf{5}$ & 4.243027 & 97.98612 & 0.773073 & 1.066361 \\
$\mathbf{6}$ & 4.686516 & 97.76101 & 0.920609 & 1.093273 \\
$\mathbf{7}$ & 5.104710 & 97.48369 & 0.790600 & 1.448394 \\
$\mathbf{8}$ & 5.503620 & 97.15695 & 0.680372 & 1.835941 \\
$\mathbf{9}$ & 5.887352 & 96.78522 & 0.589427 & 2.253618 \\
$\mathbf{1 0}$ & 6.258863 & 96.37311 & 0.515593 & 2.699188 \\
$\mathbf{1 1}$ & 6.620361 & 95.92497 & 0.456300 & 3.170593 \\
$\mathbf{1 2}$ & 6.973547 & 95.44469 & 0.409041 & 3.665992 \\
$\mathbf{1 3}$ & 7.319764 & 94.93568 & 0.371552 & 4.183759 \\
$\mathbf{1 4}$ & 7.660103 & 94.40087 & 0.341865 & 4.722455 \\
$\mathbf{1 5}$ & 7.995463 & 93.84278 & 0.318314 & 5.280813 \\
$\mathbf{1 6}$ & 8.326602 & 93.26353 & 0.299510 & 5.857713 \\
$\mathbf{1 7}$ & 8.654167 & 92.66495 & 0.284314 & 6.452156 \\
$\mathbf{1 8}$ & 8.978722 & 92.04857 & 0.271802 & 7.063250 \\
$\mathbf{1 9}$ & 9.300765 & 91.41572 & 0.261236 & 7.690190 \\
$\mathbf{2 0}$ & 9.620739 & 90.76752 & 0.252032 & 8.332245 \\
\hline & & & 0.243738 & 8.988741 \\
\hline
\end{tabular}

Figure A. 1- Impulse response of LE (IMR) on GINI and PCGHE
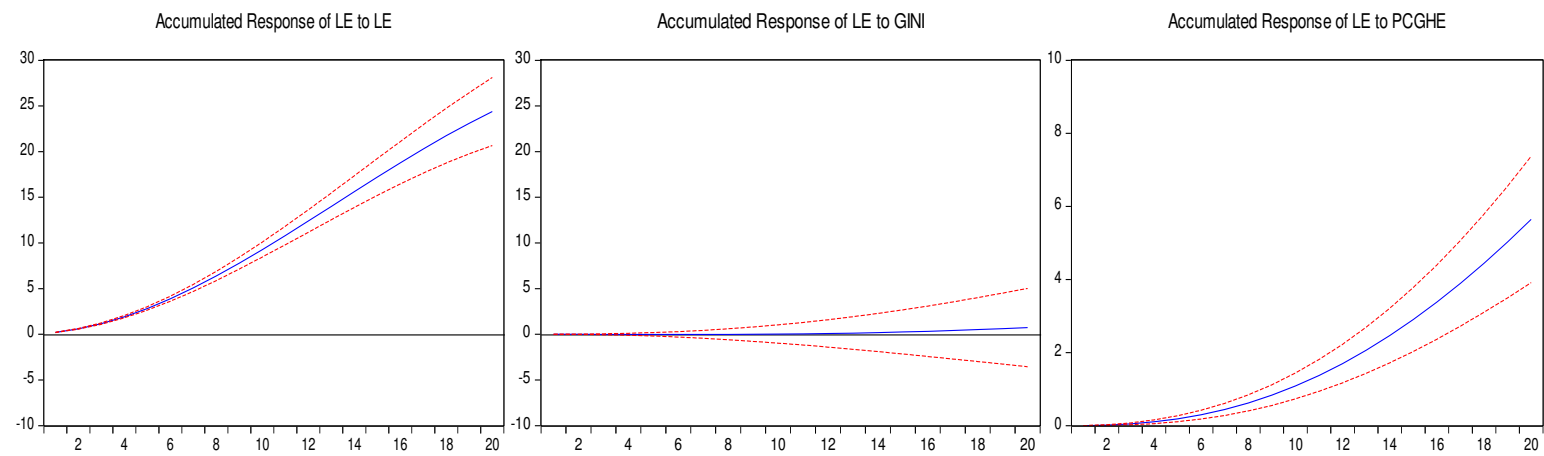

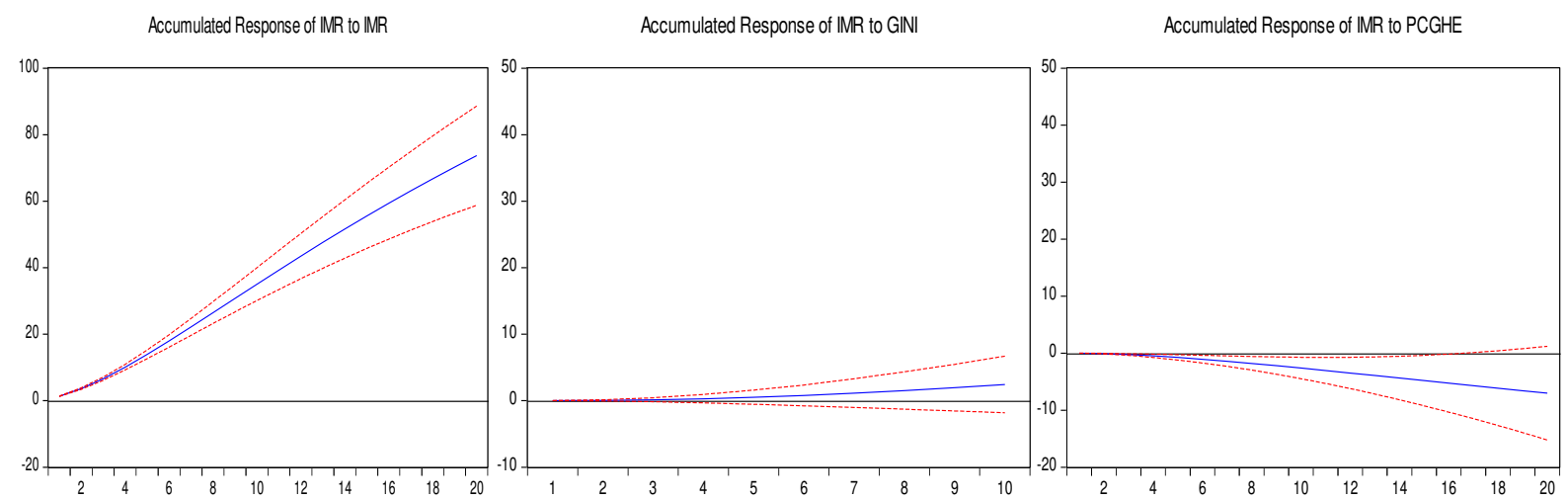

Figure A. 2- Impulse response of PSE (SSE) on GINI and GEE
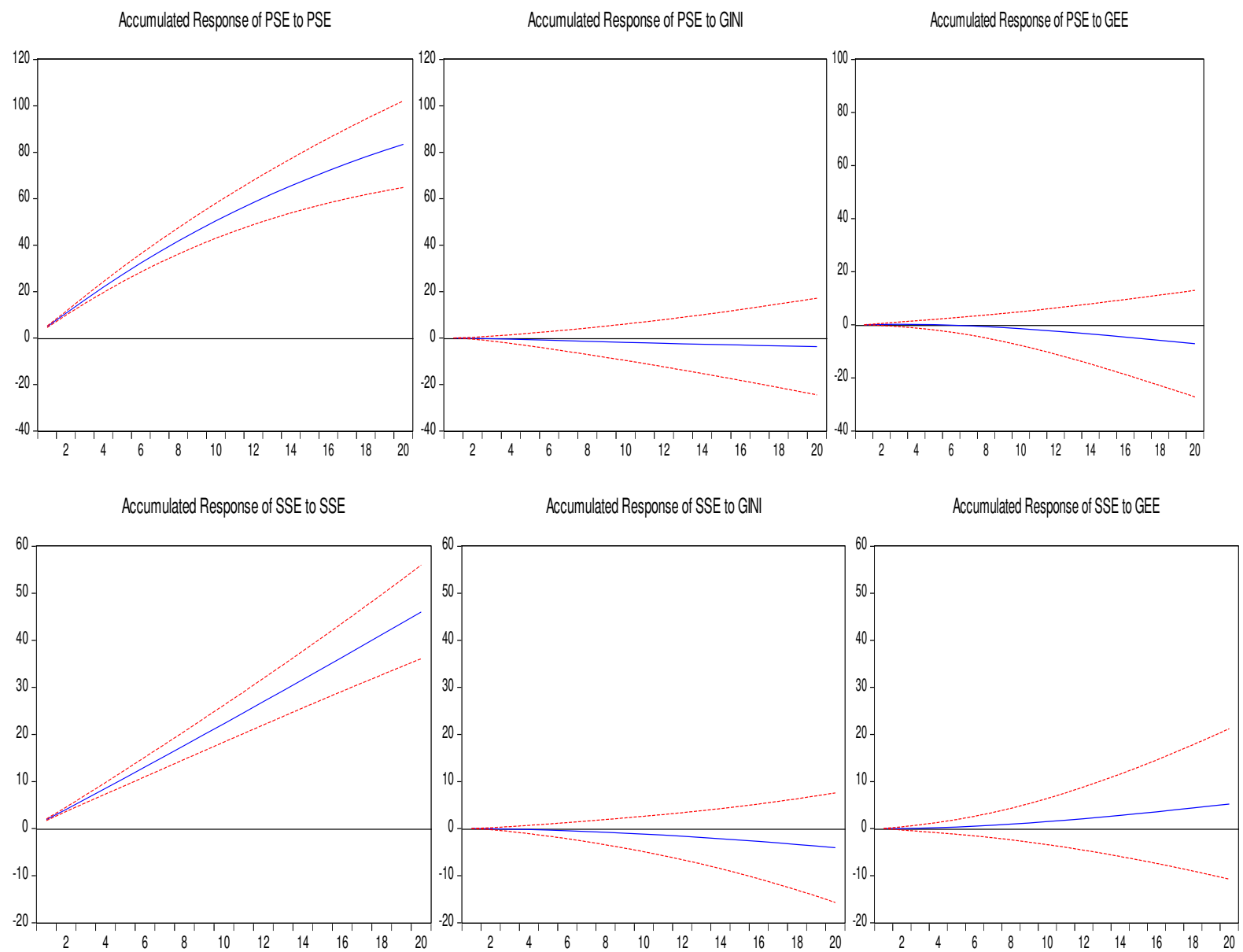